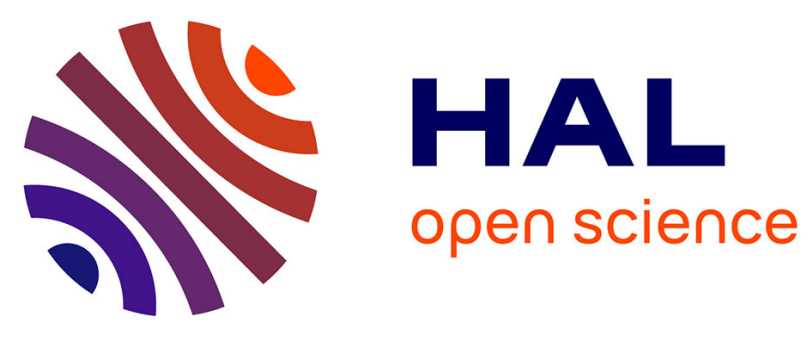

\title{
The Sugetbrak basalts from northwestern Tarim Block of northwest China: Geochronology, geochemistry and implications for Rodinia breakup and ice age in the Late Neoproterozoic
}

\author{
Bei Xu, Haibo Zou, Yan Chen, Jinyou He, Yu Wang
}

\section{To cite this version:}

Bei Xu, Haibo Zou, Yan Chen, Jinyou He, Yu Wang. The Sugetbrak basalts from northwestern Tarim Block of northwest China: Geochronology, geochemistry and implications for Rodinia breakup and ice age in the Late Neoproterozoic. Precambrian Research, 2013, 236, pp.214-226. 10.1016/j.precamres.2013.07.009 . insu-00859605

\section{HAL Id: insu-00859605}

https://hal-insu.archives-ouvertes.fr/insu-00859605

Submitted on 29 Oct 2013

HAL is a multi-disciplinary open access archive for the deposit and dissemination of scientific research documents, whether they are published or not. The documents may come from teaching and research institutions in France or abroad, or from public or private research centers.
L'archive ouverte pluridisciplinaire HAL, est destinée au dépôt et à la diffusion de documents scientifiques de niveau recherche, publiés ou non, émanant des établissements d'enseignement et de recherche français ou étrangers, des laboratoires publics ou privés. 
The Sugetbrak basaltsfrom northwestern TarimBlock ofnorthwest China: Geochronology, geochemistry and implications for Rodiniabreakupand ice age inthe Late Neoproterozoic

BeiXu $^{\text {a,** }}$, Haibo Zou ${ }^{b}$, Yan Chen ${ }^{c}$, JinyouHe ${ }^{d}$, YuWang ${ }^{a}$

${ }^{\mathrm{a}}$ Key Laboratory of Orogenic Belts and Crustal Evolution, Ministry of Education, Peking University, Beijing, 100871, China

${ }^{\mathrm{b}}$ Department of Geology and Geography, Auburn University, Auburn, AL 36849, USA

${ }^{\mathrm{c}}$ ISTO, Department of Geosciences, Orleans University, Orleans, 45067, France

${ }^{\mathrm{d}}$ China University of Geosciences, Beijing, 100083, China

${ }^{*}$ Corresponding authorE-mailaddress: bxu@pku.edu.cn (BeiXu)

Corresponding address: Department of Geology, Peking University, Beijing 100871, China 


\section{Abstract}

Zircons from two samples of the Sugetbrak basalts (SB) yieldweighted mean ages of $615.2 \pm 4.8 \mathrm{Ma}$ and $614.4 \pm 9.1 \mathrm{Ma}$. These ages,interpreted as the eruption age of the SB, providean age constraint onthe timing of theSugetbrak Formation in Sugetbrak, northwestern Tarim Block, China. These two ages suggest that the igneous activities related to the breakup of the Neoproterozoic supercontinent Rodinia lasteduntil614-615 Ma in at least the northwest Tarim Block. Geochemicalanalysis indicatesthat the SB wasgenerated in an intra-continental rifting environment.Application of the dynamic melting inversion method suggests that the Sugetbrak basalts represent 7-12\% partial melts. Unlike large-volume tholeiites, these low-degree transitional basaltic melts may represent the waning stage of plume volcanism during a long-lasting continental breakup. Based on the ages of the SB and its stratigraphic relationship with the Yuermeinak diamictite, the Yuermeinakglaciation in the Sugetbrak section of the northwest Tarim Block should correlate with theTereekenglaciation in the Qurugtagh area of the northeast Tarim Block, the Nantuo glaciation in Yangtze Block, and the Elatinaglaciation in South Australia.

Keywords: Late Neoproterozoic, Tarim Block, Rodinia, SHRIMP U-Pb age, Glaciation

\section{Introduction}

Magmatic rocks associated with the Rodiniabreakup may record critical information onthe timing and processes of continental breakup, as they can be precisely dated, and provide cluesregardingcrustal thickness and mantle sources (Kullerud et al., 2006). TheNeoproterozoic breakupof the Rodinia supercontinent has attracted much attention recently 
(Jefferson, et al., 1989; Li, et al., 1996; Veevers, et al., 1997; Wingate, et al., 1998; Li, 1999, Karlstrom, et al., 2000; Veevers, 2000; Li and Powell, 2001;Direen, et al., 2003; Li, et al., 2003; 2006; Kheraskova, et al., 2010). This event,developed in Australia, East Antarctica, Yangtze,andthe Tarim Block,is divided into four stagesin the Tarim Block: 820-800Ma, 780-760Ma, 740-735Ma and 650-635Ma (Li, et al., 1996; 2001; 2003; 2008; Li, et al., 2010; Zhang, et al., 2011; Zhang, et al., 2012). Theages of these magmatic events have been employed to constrain the division of the Neoproterozoicice ages (Ross and Villeneuve, 1997; Hoffman and Schrag, 2002; Hoffmann, et al., 2004; 2006; Zhou, et al., 2004; Condon, et al., 2005; Zhang, et al., 2005; Xu et al., 2009; Macdonald, et al., 2010).

The TarimBlock has Neoproterozoic magmatic records similar to those of the YangtzeBlock, and may have been located on the periphery of the proposed Rodiniansuperplume (Li Z.X. et al., 1999; Chen et al., 2004; Xu et al., 2005, 2009; Zhang et al., 2009; Lu et al., 2008; Shu et al., 2011).Four stages of Neoproterozoic magmatic events have been reported in the Tarim Block.The first two (820-800 Ma and 780-760 Ma) stages, represented by ultramafic-mafic complexes, adakitic granites, and mafic dykes, are interpreted to be a result of the partial melting of thickened lower crust triggered by underplating of a Rodinian superplume (Long, et al., 2011; Zhang, et al., 2009; 2011a; 2011b). The third (740-735 Ma) stage,consisting of bimodal volcanic rocks andthe fourth (650-635 Ma) stage,composed ofmafic dykes, potassic granitoids, peraluminous granite and volcanic rocks, are attributed to rifting in the Tarim Block(Xu, et al., 2005; 2009; Zhang et al., 2011; Zhu, et al., 2011). However, the presence of $615 \pm 15$ Ma volcanic rocks in the Mochia-Khutuk areaof thenortheast TarimBlock (Xu, et al., 2009), and 588-619 Ma detrital zirconsin the Aksu area of the northwest TarimBlock (Zhu, et al., 
2011), may indicate that there wasa magmatic event evenyounger than thefourth event.This is useful forinvestigatingthe waning stage of the Rodiniasuperplume breakup in the Tarim Block.

In this paper we report newages of basaltsfrom the NeoproterozoicSugetbrak Formation in the Sugetbraksection of the Aksu area, NW TarimBlock, and discuss their tectonic implications for the glaciation correlation and intra-continental riftinginthe Late Neoproterozoic.

\section{Geological setting}

2.1.Neoproterozoic strata in the Aksu area of the northwest Tarim Block

Neoproterozoic strata occur in the Aksu area of northwest Tarim, the Quruqtagh area of northeast Tarim, and the Yecheng area of southwest Tarim.Strata containing volcanicshave been found from the Aksu area and the Quruqtagh area (Gao and Zhu, 1984; Xu et al., 2005;Wang et al., 2010a, Fig. 1B).

In the Aksu area, the Neoproterozoic strata crops out in southwest Aksu,Wushi and Sugetbrak (Fig. 1C).In the sections of southwest Aksu and Wushi, the stratainclude the Aksu Group and theoverlying Sugetbrak and Chigebrak Formations. The Aksu Group is composed of pelitic, psammitic, and mafic schists.Mafic schistsarecharacterized bygreenschists and blueschists that areconsidered to besomeof the oldest high-pressure metamorphic rocks (Liou et al., 1989, 1990; 1996; Nakajima et al., 1990; Zhang, et al., 1999).A tectonic evolution modelfor the Aksublueschist has been proposed(Zhang, et al., 2010; Zhu et al., 2011). There is a clear angular unconformity between the Aksu Group and the overlying Sugetbrak Formation in southwestAksu and Wushi (Gao, et al., 1985; Turner, 2010; Zhu, et al., 2011). The 400-450 m thick Sugetbrak 
Formation is composed of red conglomerates, red fluvial sandstones and grey lacustrine mudstones with three horizons of basalts.The Chigebrak Formation is characterized by thick dolostoneand is overlainunconformably by the Cambrian Yuertus Formation (Gao et al., 1986; Turner, 2010; Zhu et al., 2011).

In the Sugetbraksection,the Neoproterozoic shows a differentsuccessioncomposed of,from bottomto top, the Qiaoenbrak, Yuermeinak,Sugetbrak and Chigebrak Formations (Fig. 2A, 2B). The Qiaoenbrak Formationis composed of epimetamorphicsandstone and siltstoneflysch,with a thickness of 1966-2094 m (Gao, et al., 1986). The glacial origin of this formation is debated. For example, Gao et al. (1993) suggestedthat it is part of a turbidite sequence. Itisunconformablyoverlain by theYuermeinak Formation and is consideredto be marineglacier deposits due to the presenceof several interbeddeddiamictites (Gao, et al., 1986). The YuermeinakFormation occurs only in the Sugetbrak area, and is characterized bydiamictites up to $61 \mathrm{~m}$ thick,which areinterpreted to becontinental glacier deposits (Gao, et al., 1986).The Sugetbrak Formation can be divided into the Lower and Upper members in Sugetbrak(Fig. 2B, 2C;Gao, et al., 1986; Zhan, et al., 2007). The Lower Sugetbrak Formation(108-461 m)is composed ofthin-layered red sandstone, quartz sandstone, siltstone and mudstone with a discontinuous horizon of 5-10 m thick basalt in its lower part, followed by $79 \mathrm{~m}$ thick volcanic rock above (Fig. 2C). The Upper Sugetbrak Formationconformably overlies the Lower member and is conformably overlain by the Chigebrak Formation. The Upper Sugetbrak Formation comprises $82 \mathrm{~m}$ thick red and grey thin-layered sandstone and mudstones with interbedded limestones (Fig. 2B, Gao, et al., 1986).

Fig. 1.(A):Tectonic location of Tarim Block in China;(B):Geological map of Tarim Block, West 
China; (C): Geological map of the Aksu area

Fig. 2. (A): Geological map of the Sugetbrak sectionand sample positions; (B): theNeoproterozoic stratigraphic column inSugetbrak; (C): photos of the Neoproterozoic strata in Sugetbrak

\subsection{Sugetbrakbasalt (SB) and samples}

The Sugetbrak basalt (SB) occurs insouthwest Aksu, Wushi andSugetbrakin the Aksu area (Fig. 1C) of thenorthwest Tarim block.There are between 2 and 4horizons of thisbasalt inthe southwest Askusection, with thicknesses of 15-30 m (Wang, et al., 2010a; Zhu, et al., 2011).Two 4-5 m thick horizons of the SB are also reported in the Wushi section45 $\mathrm{km}$ to the northwest (Turner, 2010).In the Sugetbraksection,the SB is much thicker and has repeated occurrencescaused byanE-W extending syncline. On the north limb of the syncline,a79 m thick SB occurencecrops outat the top of the Lower member of the Sugetbrak Fm. (Fig. 2B, 2C) and shows conformity relationships with the underlying sandstone (Fig. 3A), where 7 samples of A group(05822, Y1, Y2, Y5, Y6, Y7 and Y8; Fig. 2A)werecollected. Adiscontinuous horizon of 5-10 $\mathrm{m}$ thick columnar-jointed basalt (Fig. 3B) occurs in the middle of the Lower member of the Sugetbrak Fm.(Fig.2B, 2C), showing a conformity relationship with underlying sandstones. On the south limb of the syncline, a continuous horizonof the SB,characterized by pillow lava, (Fig. 3D) extends for several kilometers(Fig. 3C), andshows aconformity relationship with overlying red sandstones (Fig. 3E). Here, 9samples of B group(05823, 830S2, 831S51, 83156, 83158, 83160, 83161, 83163 and 831S81)werecollected(Fig.2A).These columnar jointed basaltsand pillow lava in the SB,combinedwith sedimentary structures, such as large herringbone (Fig. 3A) and ripplebedding (Fig. 3F) in the redsandstones, suggest a very shallow continental sedimentary environment during the period of SB magmatism.About $4 \mathrm{~km}$ southwest ofSugetbrak, two basaltic 
flows have been reported (Zhang, et al., 2012).

Fig.3. Photographs of the SB and sedimentary rocks of the Sugetbrak Formation.

\subsection{Previous geochronology for the SB}

Seventeen zircons fromthe SB fromsouthwest Aksu have been dated by the LA-ICP-MS method and yieldthree ages of $1926 \pm 27 \mathrm{Ma}, 1432 \pm 22 \mathrm{Ma}$ and $807 \pm 21 \mathrm{Ma}$. These ages have been interpreted as the ages of Mesoproterozoic metamorphic zircons and Late Neoproterozoicinherited magmatic zircons (Wang et al., 2010a). The youngest age in these inherited zircons is $755 \mathrm{Ma}$, suggesting that the SB is younger than $755 \mathrm{Ma}$ (Wang, et al., 2010a). Recently, Zhang et al.(2012) reported a LA-ICP-MS U-Pb age of 783.7 \pm 2.3 Ma from the $\mathrm{SB}$, about 4km southwest ofSugetbrak, and interpretedthis ageas thecrystallization age of the SB.

\section{Analytical procedures}

Twosamples from the SB, 05822 and 05823, wereanalyzedby the SHRIMP U-Pb method for age dating. In addition, these twosamples and the 14 other SBsampleswereanalyzedto determinetheir major and trace elements compositions.

Zircons for SHRIMP analyses were separated from samples 05822 and 05823 in the SB according to magnetic properties and density, and purified by hand picking. The zircons, together with several grains of TEMORA, were cast in an epoxy mount and polished down to half section. Cathodoluminescence (CL) imaging was used to guide the SHRIMP analyses. The CL study was undertaken on a FEI-XL30SFEG electron microscope at the Department of Electronics, Peking University. 
The SHRIMP U-Pb analyses wereperformed on the Beijing SHRIMP Ihat the ChineseAcademy of Geological Sciences, Ministry of Land and Resource of Peoples' Republic of China. The analytical procedures followed the methodology of Williams et al (1987) and Compston et al (1992). For the zircon analyses, nine ion species of $\mathrm{Zr}_{2} \mathrm{O}^{+},{ }^{204} \mathrm{~Pb}^{+},{ }^{207} \mathrm{~Pb}^{+},{ }^{206} \mathrm{~Pb}^{+}$, ${ }^{208} \mathrm{~Pb}^{+}, \mathrm{U}^{+}, \mathrm{Th}^{+}, \mathrm{ThO}^{+}, \mathrm{UO}^{+}$and background weremeasured on a single electron multiplier by cyclicstepping of the magneticfield, recording the mean ion counts of every 7 scans. A primary ion beam of c. $4.5 \mathrm{nA}, 10 \mathrm{kV} \mathrm{O}^{-2}$ and c. $20-25 \mu \mathrm{m}$ spot diameterwas used. Masses were analyzedat a mass resolution of c. 5000 (1\% peakheight). Interelementfractionation in the ion emission of zircon wascorrected relative to the ANU RSES references, using the TEMORA (417 Ma, ${ }^{206} \mathrm{~Pb}^{*}$ ) ${ }^{238} \mathrm{U}=0.06683$ ). Errors on individualanalysis are at the $1 \sigma$ levelbased on countingstatistics. The reproducibility of TEMORAwasrepeatedlymeasuredat c. 3\%. The software of Ludwig SQUID1.0 and attached ISOPLOT wereused for data processing (Ludwig, 1999; 2001). The ages werecalculatedusing the decayconstants recommended by IUGS (1977). The weightedmeanages werequotedat a 95\% confidence level. The initial lead component was corrected using measured ${ }^{204} \mathrm{~Pb}$.

Major element oxides were determined by $\mathrm{x}$-ray fluorescence using glass disks at the Laboratory of Orogenic Belts and Crustal Evolution, Ministry of Education, Peking University. Analytical precision as determined on duplicate analyses was generally around $1-5 \%$. For trace element analyses, about $50 \mathrm{mg}$ sample powders were dissolved using a $\mathrm{HF}+\mathrm{HNO}_{3}$ mixture in a Teflon bomb at $\sim 190{ }^{\circ} \mathrm{C}$ for $48 \mathrm{~h}$. Trace elements were analyzed using a Finnigan Element IIICP-MS at the Center of Modern Analysis, Nanjing University. Analytical precision for trace elements was better than 5\%. Detailed analytical procedure followedGao et al. (2003). 


\section{U-Pb zircon geochronology}

The measured isotopic ratios and calculated ages for samples 05822 and 05823 are given in Table 1 and illustrated on Concordia plots in Fig. 4B. The measured U concentrations for these zircon grains vary from 960 to $58 \mathrm{ppm}$; Th, from 949 to $63 \mathrm{ppm}$; and $\mathrm{Th} / \mathrm{U}$ ratios, from 1.59 to 0.26 , which suggests that all zircons belong to a magmatic type.

Twenty-nine zircons were dated in total, and can be divided into threeage groups (Table 1).Zircons ofgroup1are $150 \mu \mathrm{m}$ in size,show weakly zoned textures (Fig. 4A, 05823-11-4.1),and yield a ${ }^{207} \mathrm{~Pb} /{ }^{206} \mathrm{~Pb} \quad$ age of $\quad 1756 \pm 9$ Ma (Table 1, 05823-11-4.1), indicatingthe Mesoproterozoicmagmatism (Hu, et al., 2000). Most zircons of groups2 and 3 are smaller, ranging from 80 to $30 \mu \mathrm{m}$.Theyare euhedral with oscillatoryzoning,indicative of magmatic zircons (Fig. $4 \mathrm{~A}){ }^{206} \mathrm{~Pb} /{ }^{238} \mathrm{U}$ ages of twenty-fourzircons ofgroup 2 range from 676 to $864 \mathrm{Ma}$, and form several intervals of $676-691 \mathrm{Ma}(\mathrm{n}=3), 707-743 \mathrm{Ma}(\mathrm{n}=5), 751-790 \mathrm{Ma}(\mathrm{n}=7)$ and $806-864 \mathrm{Ma}(\mathrm{n}=9$, Table 1). These ages represent inherited zircon ages andreflect multiple magmatic episodesrelated toRodinia breakup inthe Late Neoproterozoic(Zhang, et al., 2011b; Zhu et al., 2011b; Wang, et al., 2010a).Interestingly, there are four zircons in group 3 that yield ${ }^{206} \mathrm{~Pb} /{ }^{238} \mathrm{U}$ ages from 617 to 612 Ma (05822-1-7.1, 05822-1A-5.1, 05823-11-2.1 and 05823-11-5.1), which give twoconcordia ages

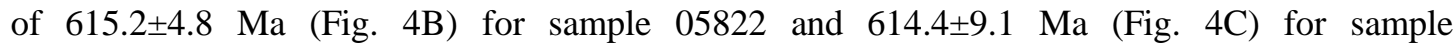
05823.Because these 4 youngest zircons areeuhedral and thesmallestin size, their concordia ages of 614-615Maare interpreted as the eruption age of the SB, although we cannot completely rule out the possibility that the $\sim 615$ Ma zircons may represent the youngest inherited zircons. In the case of youngest zircon inheritance, the eruption age of the Sugetbrak basalts would be slightly 
younger than $\sim 615 \mathrm{Ma}$.

Table 1. Zircon U-Pb isotopic data

Fig. 4. Cathodoluminescence images and Zircon concordia plots

\section{Geochemistry}

Major and trace elements of the SB are listed in Table 2.They are characterized by high $\mathrm{TiO}_{2}$ contents (2.2-4.0\%). Their $\mathrm{Al}_{2} \mathrm{O}_{3}$ ranges from $13.9 \%$ to $17.7 \%$. Total alkali content ranges from $2.9 \%$ to $5.4 \%$, with $\mathrm{Na}_{2} \mathrm{O}>\mathrm{K}_{2} \mathrm{O}$. Theirhigh LOI contents, ranging from $2.7 \%$ to $8.7 \%$, indicate alterations. $\mathrm{Na}_{2} \mathrm{O}$ and $\mathrm{K}_{2} \mathrm{O}$ were probably mobile during alterations, and thus cannot be employed for rock classifications using the total alkali vs. silica diagram.

Table 2. Major and trace elements of the SB

Petrologically, it is useful to determine whether the rocks are alkali basalts or tholeiites. Here we use immobiletrace elements such as $\mathrm{Nb}$ and $\mathrm{Y}$ to further evaluate their alkali character. These samples have $\mathrm{Nb} / \mathrm{Y}$ ratios ranging mostly from 0.58 to 0.68 . In the $\mathrm{Zr} / \mathrm{TiO}_{2}-\mathrm{Nb} / \mathrm{Y}$ diagram (Winchester and Floyd, 1977), they plot on the boundary line between sub-alkaline basalts and alkali basalts (Fig. 7A). In the $\mathrm{Nb} / \mathrm{Y}-\mathrm{Zr} /\left(\mathrm{P}_{2} \mathrm{O}_{5} * 10000\right)$ diagram, they also plot near the boundary line between alkali basalts and tholeiitic basalts (Fig. 7B). We thus regard them as transitional basalts.

Fig. 5. A: $\mathrm{Zr} / \mathrm{TiO}_{2}-\mathrm{Nb} / \mathrm{Y}$ diagram (Winchester and Floyd, 1977)

B: $\mathrm{Nb} / \mathrm{Y}-\mathrm{Zr} /\left(\mathrm{P}_{2} \mathrm{O}_{5} * 10000\right)$ diagram (Floyd and Winchester, 1975)

All samples are enriched in light rare earth elements (LREEs, Fig. 6A). They lack negative Eu anomalies, indicating that plagioclase is not a fractionatingphase.In the Spider diagram (Fig. 
6B), they display positive anomalies in $\mathrm{Ba}$ and $\mathrm{Pb}$ and negative anomalies in $\mathrm{Rb}$ and $\mathrm{Sr}$. They do not shownegative $\mathrm{Nb}$ anomalies.

Fig. 6.A: REE diagram; B: Spider diagram

\section{Discussion}

6.1 Petrogenesis and tectonic settings

6.1.1Within-plate environments

$\mathrm{Ti}, \mathrm{Zr}, \mathrm{Y}$ and $\mathrm{Nb}$ are immobile trace elements during zeolite to greenschistfacies metamorphism, and may be useful for the determination of tectonic environments of basaltic rocks (Pearce and Cann, 1973; Winchester and Floyd, 1975). In the Ti-Zr-Y diagram (Pearce and Cann, 1973), the lavas plot in the "within-plate" basalt field (Fig. 7A). In the Nb-Zr-Y diagram (Meschede, 1986), the samples plot on the boundary line between fields AII and C, indicating an intraplate tectonic setting (Fig. 7B). Theboundary line is the transition between intraplate alkali basalts and intraplatetholeiites.Both Ti-Zr-Y and Nb-Zr-Y diagrams suggest a within-plate environment, ruling out the possibility of a volcanic arc or ocean-ridge environment.The lack of any negative $\mathrm{Nb}$ anomaly in the spider diagram also argues against the island arc or continental arc environment.Therefore, the SBare intra-continental transitional basalts.Our inference of a within-plate (intra-continental) tectonic setting for the SB is largely consistent with the work by Zhang et al. (2012).

Fig. 7. A: Ti-Zr-Y diagram (Pearce and Cann, 1973); 


\subsubsection{Low-degree small-volume melts}

The high Ti contents in all samples reflect low degree partial melts. We have used the dynamic melting inversion (DMI) method (Zou and Zindler, 1996; Zou, 1998; Zou et al., 2000) to estimate the degrees of partial melting more quantitatively. The DMI method uses variations of between-magma concentration ratios for two incompatible elements with different partition coefficients, and does not require assumptions about mantle rock concentrations or ratios. Two immobile trace elements are selected with different partition coefficients, $\mathrm{Nb}$ and $\mathrm{Zr}$. Note that Nbis more incompatible than $\mathrm{Zr}$. The concentration ratios between a low-degree melt sample (sample 831S41) and a high-degree melt sample (sample 83161) are $1.51(=24.63 / 16.27)$ for $\mathrm{Nb}$ and $1.31(=200 / 152)$ for Zr. Samples 831S41 and 83161 are selected because sample 831S41 has the highest incompatible element concentrations (representing the lowest degree of partial melting) while sample 83161 has the lowest incompatible element concentrations (indicative of the highest degree of melting) in B Group. The degree of partial melting calculated using DMI by solving a system of simultaneous non-linear equations is $7.4 \%$ for sample $831 \mathrm{~S} 41$, and $10.9 \%$ for sample 83161, using bulk partition coefficients of 0.01 for $\mathrm{Nb}$ and 0.04 for $\mathrm{Zr}$. If we still select sample 831S41 as a low-degree melt, but select another sample such as 83160 as a high-degree melt (another sample with low incompatible element concentrations in B Group), then the low-degree/high-degree concentration ratios are $1.52(=24.63 / 16.27)$ for Nband $1.33(=200 / 150)$ forZr, and the partial melting degrees using DMI are $7.9 \%$ for sample $831 \mathrm{~S} 41$ and $11.8 \%$ for sample 83160 . Thus, these transitional basalts were produced at $7-12 \%$ mantle partial melting. 
Note that in the calculations we use concentration ratios instead of elemental abundances, because concentration ratios are insensitive to subsequent fractional crystallizations.

Unlike large-volume tholeiitesproduced in the main stage of plume volcanism, these low-degree, small-volume melts might represent melts formed at the onset stage or the waning stage of a plume during continental breakup. We prefer to considerwaning stage of plume volcanism for the creation of the SB because of its younger age, while Zhang et al. (2012) prefer the onset stage of plume volcanism, owing to the different age results for the SB (784 Ma in Zhang et al. (2012) vs. 614-615 Ma from this study). As mentioned above, we regard the $784 \mathrm{Ma}$ age as the age for inherited zircons (see discussion in section 6.2).

6.2. Implications for the rift succession of the Sugetbrak Formation and Neoproterozoic igneous activities

Because the studied samples were collected in the horizons of the SB between the Lower and Upper Sugetbrak members, the new age representsthe boundary age between the upper and lower members, further providing a time constraint on the timing oftheSugetbrak Formation in the Sugetbrak section. Recently, the Sugetbrak Formation in the southwestAksu and Wushi areas has been interpreted as fluvial and lacustrine faciessediments (Turner, 2010; Wang et al., 2010a). Combinedwith several horizons of basalts that record episodic volcanism, these sedimentary faciesarethoughtto indicate the development of a Neoproterozoic rift system in the Aksu area (Turner, 2010; Wang et al., 2010a).Hence, our new age represents the development age of this rift system in the northwest Tarim Block.

Though four phases of Neoproterozoic igneous activities (820-800Ma, 780-760Ma, 
740-735Ma and 650-635Ma) have been recognized in the TarimBlock(Zhang et al., 2011), ournew age $(615 \mathrm{Ma})$ is even younger,and may represent thelast stage of the Neoproterozoic rifting relating to thebreakup of the Rodinia Supercontinent in the northwest Tarim Block. It has been noticed that there aresimultaneousvolcanic rocks in the Qurugtagh area of thenortheast Tarim Block, where an age of $615 \pm 6 \mathrm{Ma}$ from andesitic lava has been reported (Xu et al., 2009). These data suggest that the igneous activities related to the breakup of the Neoproterozoic Rodinia supercontinent lasteduntil at least $615 \mathrm{Ma}$.

Six detrital zircon ages from the red sandstone of the Sugetbrak Formationin southwestAksurange from 619 to $588 \mathrm{Ma}$ and give a weighted average age of $602 \pm 13 \mathrm{Ma}$ (Zhu, et al., 2011), which isyounger thanthe ageof the SB from Sugetbrak. The age difference betweentheseplaces might be due to the fact that the Neoproterozoic succession in southwest Aksuis incomplete, which has been indicated by the lacunas of the Qiaoenbrak and Yuermeinak Formations, and of thebottom part ofthe Lower Sugetbrak Formation (Fig. 8). Turner (2010) pointedout that small, isolated depocentres and pre-existing topography might causelocal variety of basal conglomerates in the Aksu area. Therefore,the age of $602 \pm 13$ Ma might represent the maximal depositional age of the Upper member of theSugetbrak Formation (Fig. 9). Obviously, the direct evidence for the age of the Sugetbrak Formation depends on the eruption age of the SB in the southwest Aksu section. According to available geochronological data in the southwest Aksu and Sugetbraksections, a revised correlation of the Neoproterozoic strata between southwest Aksu, Wushi and Sugetbraksections is proposed in Fig. 8.

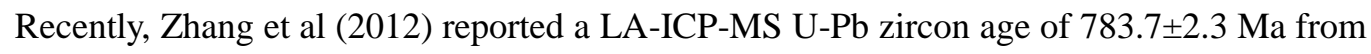
the SB about $4 \mathrm{~km}$ southwest ofSugetbrak, and interpreted it as a crystallization age of the SB. We 
regard $784 \mathrm{Ma}$ as the age for inherited zircons instead of the crystallization age for the SB, because the zircons from Zhang et al. (2012) are large crystals (most zircons $>80 \mu \mathrm{m}$ ), similar to group 2 zircons of this study and the inherited zircons of Wang et al. (2010a). In addition, Zhu et al. (2011) have reported several detrital zircon ages ranging from 619 to $588 \mathrm{Ma}$ from the red sandstone of the Upper member of the Sugetbrak Formation, which implies that it is impossible for the Lower member of this formation to be 784 Ma old. Geologically, if this age of $784 \mathrm{Ma}$ is correct, then the underlying Yuermeinak glacier deposits would be older than 784 Ma. However, no Neoproterozoic ice age older than 784 Ma has been reported in the world (Hoffman and Schrag, 2002; Xu, et al., 2009; Macdonald, et al., 2010).

Fig. 8. Correlation of the Neoproterozoic strata between southwest Aksu, Wushi and Sugetbrak areas

6.3. Implications for thecorrelation of the Yuermeinak glaciation

Ages, distribution, and correlationsof the Neoproterozoic glaciations around the worldare still controversial(Kaufman et al., 1997; Hoffman et al., 1998; Kennedy et al.,1998; Hoffman and Schrag, 2002; Jiang et al., 2003). Two glaciations (Sturtian and Marinoan, Young, 1995; Kennedy et al., 1998), three glaciations (Sturtian, Marinoan and post-Marinoan, Knoll, 2000, Xiao et al., 2004; Halverson, 2006; McCay et al., 2006)orfourglaciations (Kaigas, Sturtian,Marinoan or Elatina and Gaskiers, Hoffman and Schrag, 2002; Hoffmann et al., 2004;Macdonald et al., 2010)have been proposed.On the other hand, four glaciations have been reported in the northeast Tarim Block, including Bayisi (730 Ma), Altungol, Tereeken (725-615 Ma) and Hankalchough 
(615-542 Ma) glaciations (Kou et al., 2008; Xu et al., 2008; Xu et al., 2009). However, the age of the Yuermeinakglaciation in the northwestTarim Block,and its correlation,werepreviously unknown.

According to the Neoproterozoic succession in theSugetbraksection(Fig. 9), the Lower member of Sugetbrak Formation containing the SBconformably overlies the Yuermeinak Formationdiamictite.Because there is only about $400 \mathrm{~m}$ of continental sedimentary succession between the SB and Yuermeinak Formation, the occurrence of the Yuermeinak glaciation is not much earlier than 614-615 Ma. This is similartothe Tereeken glaciation in the Quruqtagh area of the northeast Tarim Block, where there is only the ZhamoketiFormation turbidite between the Tereekendiamictite and volcanic layerwith an age of $615 \pm 6$ Ma (Xu et al., 2009).It is thereforereasonableto correlatethe Yuermeinake glaciationwith the Tereeken glaciation in the Quruqtagh area.Based on aTIMS U-Pb age of $635.2 \pm 0.6 \mathrm{Ma}$ for the Nantuo glaciation (Condon et al., 2005) and an age of $615 \pm 6$ Ma for the volcanic rocks above the Tereeke glaciation,previous studies havesuggested that the Tereekenglaciation can be correlated with the Nantuoglaciation in the Yangtze Blockand the Elatina glaciation in Australia (Xu et al., 2009). If this is correct,then the Yuermeinak glaciation should also correlate with them (Fig. 10).

Fig. 10Correlation of the Neoproterozoicglaciations

\section{8. Conclusion}

This study reached the following conclusions:

(1)Small euhedralzircons from two samples of the Sugetbrak basalts (SB) of the Sugetbrak Formationyieldweighted mean ages of $615.2 \pm 4.8 \mathrm{Ma}$ and $614.4 \pm 9.1 \mathrm{Ma}$. These ages are interpreted 16 
as the eruption age of the $\mathrm{SB}$, thereby providing an age constraint on the timing oftheSugetbrak Formation in Sugetbrak, northwestTarim Block. These two ages suggest that the igneous activities related to the breakup of the Neoproterozoic Rodinia supercontinent lasteduntil at least614-615 Ma in the northwest Tarim Block.

(2)Geochemicalanalysis indicatesthat the SB was generated in an intra-continental rifting environment.Application of the dynamic melting inversionmethod suggests thatthe degree of partial melting of the SB ranges from $7 \%$ to $12 \%$. Unlike large-volume tholeiites, these low-degree transitional basaltic melts may represent the waning stage of plume volcanism during a long-lasting continental breakup.

(3)Based on the new ages of the SB and its relationship with the Yuermeinak diamictite, the Yuermeinakglaciation in Sugetbrak of the northwest Tarim Block should correlate with theTereekenglaciation in the Qurugtagh area of the northeast Tarim Block, the Nantuo glaciation in theYangtze Block and the Elatinaglaciation in Australia.

\section{Acknowledgements}

We are grateful toanonymous reviewers for their constructive reviews that significantly improved the quality of this paper. We also thank Biao Song for his help in SHRIMP analyses of zircons, Chen Peng, Wei Wei, and Tong Qinlongfor field assistance, and Li Huaikun and Wang Yanyang for drawing figures. Ross T. Tucker and Erin Summerlin from Auburn University provided helpful in-house reviews. This study was supported by grants from the National Natural Science Foundation of China $(40972126,41121062)$. 


\section{References}

BGMRED of Xinjiang, 1993.Regional Geology of Xinjiang Uygur Autonomous Region.Geol.

Publ. House, Beijing, 841pp (in Chinese with English abstract).

Bullerud, K., Skjerlie, K.P., Corfu, F., de la Rosa, J., 2006. The 2.40 GaRingvassoy mafic dykes, West Troms Basement Complex, Norway: The concluding act of early Palaeoproterozoic continental breakup. Precambrain Res. 150, 183-200.

Chen, Y, Xu, B, Zhan, S., Li, Y.A., 2004. First mid-Neoproterozoicpaleomagnetic results from the Tarim Basin (NW China) and their geodynamic implications. Precambrian Res. 133, 271-281.

Chu, XL., Todt, W., Zhang, QR., Chen, FK., Huang J., 2005. U-Pb zirconage for the NanhuaSinian boundary. Chinese Science Bulletin, 50 (7): 716-718.

Compston, W., Williams, I.S., Kirschvink, J.L., Zhang, Z., Ma, G., 1992.Zircon U-Pb ages of early Cambrian time-scale. J. Geol. Soc. 149, 171-184.

Condon, D., Zhu, M., Bowring, S., Wang, W., Yang, A., Jin, Y., 2005. U-Pb ages fromthe NeoproterozoicDoushantuo Formation. Chin. Science 308, 95-98.

Direen, N., Crawford, A., 2003, Fossil seaward-dipping reflector sequences preserved in southeastern Australia:a 600 Ma volcanic passive margin in eastern Gondwanaland.Journal of the Geological Society, London. 160, 2003, 985-990.

Gao, J.F., Lu, J.J., Lai, M.Y., 2003. Analysis of trace elements in rock samples using HRICP-MS. Journal of Nanjing University (Natural Sciences) 39, 844-850 (in Chinese with English abstract)

Gao, Z., Zhu, C., 1984. Precambrian Geology in Xinjiang, China.Urumqi, pp. 1-151 (in Chinese with English abstract).

Gao, Z., Qian, J., 1985. Sinian glacial deposits in Xinjiang, Northwest China.Precambrian Res. 29, 
143-147.

Gao, Z., Wang, W., Peng, C., Li, Y., Xiao, B., 1985.The Sinian System of Xinjiang.Urumqi, pp. 1-173 (in Chinese with English abstract).

Gao, Z., Wang, W., Peng, C., Li, Y., Xiao, B., 1986.The Sinian System on Aksu-Wushi Region, Xinjiang.Urumqi, pp. 1-184 (in Chinese with English abstract).

Hoffman, P.F.,Schrag, D.P., 2002. The snowball Erath hypothesis:testing the limits of global change, Terra Nova 14, 129-155.

Hoffmann, K.-H., Condon, D.J., Bowring, S.A., Crowley, J.L., 2004. U-Pb zircon date from the NeoproterozoicGhaub Formation Namibia: constraints on Marinoanglaciation. Geology 32, $817-820$.

Hoffmann, K.-H., Condon, D.J., Bowring, S.A., Prave, A.R., Fallick, A., 2006. Lithos-tratigraphic, carbon $\left({ }^{13} \mathrm{C}\right)$ isotope and $\mathrm{U}-\mathrm{Pb}$ zircon age constraints on earlyNeoproterozoic (ca. $755 \mathrm{Ma}$ ) glaciation in the Gariep Belt, southern Namibia. In:Proceedings of the Snowball Earth Conference, July 16-21, 2006, Monte Verita,Ticino, Switzerland, p. 51.

Hu, A.Q., Jahn, B.M., Zhang, G.X., Chen, Y.B., Zhang, Q.F., 2000. Crustal evolutionand Phanerozoic crustal growth in northern Xinjiang: $\mathrm{Nd}$ isotope evidence, 1.Isotopic characterization of basement rocks. Tectonophysics 328, 15-51.

Jefferson, C.W., Parrish, R.R., 1989. Late Proterozoic stratigraphy, U-Pb zircon ages,and rift tectonics, Mackenzie Mountains, northwestern Canada. Can. J. Earth Sci.26, 1784-1801.

Jiang, G., Kennedy, M.J., Christie-Blick, N., 2003. Stable isotopic evidence for methaneseeps in Neoproterozoic postglacial cap carbonates. Nature 426, 822-826.

Karlstrom, K.E., Bowring, S.A., Dehler, C.M., Knoll, A.H., Porter, S.M., Marais, D.J.D.B.,Weil, 
A., Sharp, Z.D., Geissman, J.W., Elrick, M.B., Timmons, J.M., Crossey, L.J.,Davidek, K.L., 2000. Chuar Group of the Grand Canyon: Record of breakup ofRodinia, associated change in the global carbon cycle, and ecosystem expansionby $740 \mathrm{Ma}$. Geology 28, 619-622.

Kennedy, M.J., Runnegar, Kheraskova, T. N., Bush, V. A.,Didenko, A. N.,Samygin, S. G., 2010. Breakup of Rodinia and Early Stages of Evolution of the Paleoasian Ocean.Geotectonics 44, 3-24.

Kou, X.,Wang, Y., Wei, W., He, J., Xu, B., 2008. The NeoproterozoicAltungol and Huangyanggou formations in Tarim plate: recognized Newly glaciation and interglaciation. ActaPetrologicaSinica 24, 2863-2869 (in Chinese with English abstract).

Li, X.H., Li, Z.X., Zhou, H.W., Liu, Y., Kinny,P.D., 2002. U-Pb zircon geochronology, geochemistry and $\mathrm{Nd}$ isotopic study of Neoproterozoic bimodal volcanic rocks in the Kangdian Rift of South China: implications for the initial rifting of Rodinia. Precambrian Res. $113,135-154$

Li, X.H., Li, Z.X., Ge, W., Zhou, H., Li, W., Liu, Y., Wingate, M.T.D., 2003.Neoproterozoicgranitoids in South China: crustal melting above a mantle plume at ca. 825 Ma?Precambrian Res. 122, 45-84.

Li, X.H., Li, Z.X., Wingate, M.T.D., Chung, S.L., Liu, Y., Lin, G.C., Li, W.X., 2006.Geochemistry of the 755 Ma MundineWell dyke swarm, northwestern Australia: part of a Neoproterozoic mantle superplume beneath Rodinia? Precambrian Res. 146, 1-15.

Li, X.H., Zhu, W.G., Zhong, H., Wang, X.C., He, D.F., Bai, Z.J., Feng, L., 2010. The Tongdepicritic dikes in the Western Yangtze Block: evidence for ca 8oo-Ma mantle plume magmatism in south China during the breakup of Rodinia. J. of Geol. 118 509-522. 
Li, Z.X., Zhang, L., Powell, C.M., 1996. Positions of the East Asian cratons in the Neoproterozoicsupercontinent Rodinia, Aust. J. Earth Sci. 43, 593-604.

Li, Z.X., Li, X.H., Kinny, P.D., Wang, J., 1999. The breakup of Rodinia: Did it start with a mantle plume beneath South China? Earth Planet. Sci. Lett. 173, 171-181.

Li, Z.X., Powell, C.M., 2001. An outline of the palaeogeographic evolution of the Australasian region since the beginning of the Neoproterozoic. Earth Sci. Rev. 53, 237-277.

Li, Z.X., Li, X.H., Kinny, P.D., Wang, J., Zhang, S., Zhou, H., 2003. Geochronology of Neoproterozoicsyn-rift magmatism in the Yangtze Craton, South China and correlations with other continents: evidence for a mantle superplume that broke up Rodinia. Precambian Res. $122,85-110$.

Li, Z.X., Bogdanova, S.V., et al. 2008. Assembly, configuration, and break-uphistory of Rodinia: A synthesis. PrecambrianResearch, $160,179-210$.

Ling, W., Gao, S., Zhang, B., Li, H., Liu, Y., Cheng, J., 2003. Neoproterozoic tectonic evolution of the northwestern Yangtze craton, South China: implications for amalgamation and break-up of the Rodinia Supercontinent. Precambian Res.122, 111-140.

Liou, J.G., Graham,S.A.,Mayuyama, S., Wang, X., Xiao, X., Carrroll, A. R., Chu, J., Feng, Y., Hendrix, M.S., Liang, Y., Mcknight, C.L., Yang, Y., Wang, Z., Zhao, M., Zhu. B., 1989. Proterozoicblueschistbelt in westernChina: Best-documentedPrecambrianblueschists in the world.Geology 17,1127 -1131.

Liou, J.G., Maruyama, S., Wang, X., Graham, S., 1990. Precambrianblueschistterranes of the world. Tectonophysics 181, 97-111.

Liou, J.G., Graham, S.A., Maruyama, S., Zhang, R.Y., 1996. Characteristicsand 
tectonicsignificance of the LateProterozoicAksublueschists anddiabasicdikes, NorthwestXinjiang, China. International GeologicalReview38, 228 -244.

Long, X.P., Yuan, C., Sun, M., Kröner, A., Zhao, G.C., Wilde, S., Hu, A., 2011. Reworking of the Tarim Craton by underplating of mantleplume-derivedmagmas: Evidence from Neoproterozoicgranitoids in the Kuluketagearea, NWChina. Precambian Res.187, 1-14.

Lu, S., Li, H., Zhang, C., Niu, G., 2008.Geological and geochronological evidence for the Precambrian evolution of the TarimCraton and surrounding continental fragments.Precambian Res.160, 94-107.

Ludwig, K.R., 1999. Using Isoplot/EX, version 2, a geolocronolgical Toolkit for Microsoft Excel. Berkeley Geochronological Center Special Publication 1a, 47.

Ludwig, K.R., 2001. Squid 1.02: A user manual.BerkeleyGeochronological Center Special Publication 2, 19.

Macdonald, F.A., Schmitz, M.D., Crowley, J.L., Roots, C.F., Jones, D.S., Maloof, A.C., Strauss, J.V., Cohen, P.A., Johnston, D.T., Schrag, D.P., 2010. Calibrating the Cryogenian. Science 327, 1241-1243.

Meschede, M., 1986.A method of discriminating between different types of mic-ocean ridge basalts and continental tholeiites with the Nb-Zr-Y diagram. Chem. Geol. 56, 207-218.

Nakajima, T., Maruyama, S., Uchiumi, S., Liou, J.G., Wang, X., Xiao, X., Graham, A., 1990.Evidence for late Proterozoic subduction from 700-Myr-old blueschists in China. Nature $346,263-265$

Pearce, J.A., Cann, J.R., 1973. Tectonic setting of basic volcanic rocks determined using trace element analyses. Earth Planet. Sci. Lett. 19, 290-300. 
Ross, G.M., Villeneuve, M.E., 1997. U-Pb geochronology of stranger stones in Neoproterozoicdiamictites, Canadian Cordillera: implications for provenance and ageof deposition. Geological Survey of Canada, Current Research 1997-F, 141-155.

Shu, L.S., Deng, X.L., Zhu, W.B., Ma, D.S., Xiao, W.J., 2011. Precambrian tectonic evolution of the Tarim Block, NW China: New geochronological insights from the Quruqtagh domain. J. Asian Earth Science 42, 774-790.

Turner, S., 2010. Sedimentary record of Late Neoproterozoic rifting in the NW Tarim basin,China. Precambrian Res. 181, 85-96

Veevers, J., 2000. Billion-year Earth History of Ausrealia and its Neighbours in Gondwanaland. GEMOD Press, Sydney

Veevers, J.J., Walter, M.R., Scheibner, E., 1997. Neoproterozoic tectonics of Australia-Antarctica and Laurentia and the 560 Ma birth of the Pacific ocean reflect the 400 m.y. Pangeansupercycle. J. Geol. 105, 225-242.

Wang, F., Wang, B., Shu, L., 2010a. Continental tholeiitic basalt of the Aksu area (NW China) and its implication for the Neoproterozoic rifting in the northern Tarim.ActaPetrologicaSinica 26, 547-558.(in Chinese with English abstract).

Wang, Y., He, J., Wei, W.,Xu, B., 2010b. Study on the late Proterozoic sedimentary facies and sequence stratigraphy in Aksu area, Xinjiang. ActaPetrologicaSinica 26, 2519-2528 (in Chinese with English abstract).

Williams, I.S., Claesson, S., 1987. Isotope evidence for the Precambrian province and Caledonian metamorphism of high grade paragneiss from the SeveNappes, Scandinavian Caledonides, II Ion microprobe zircon U-Th-Pb. Contrib. Mineral. Petrol. 97, 205-217. 
Winchester, J.A., Floyd, P.A., 1977. Geochemical discrimination of different magma series and their differentiationproducts using immobile elements. Chem. Geol. 20, 325-343.

Wingate, M.T.D., Campbell, I.H., Compston, W., Gibson, G.M., 1998. Ion microprobe U-Pb ages for Neoproterozoic basaltic magmatism in south-central Australia and implications for the breakup of Rodinia. Precambrian Res. 87, 135-159.

Xiao, S., Bao, H., Wang, H., Kaufman, A.J., Zhou, C., Li, G., Yuan, X., Ling, H., 2004. TheNeoproterozoicQuruqtagh Group in eastern Chinese Tianshan: evidence for apost-Marinoan glaciation. Precambrian Res. 130, 1-26.

Xu, B., Jian, P., Zheng, H., Zou, H., Zhang, L., Liu, D., 2005. U-Pb zircon geochronology and geochemistry of Neoproterozoic volcanic rocks in the Tarim Block of Northwest China: implications for the breakup of Rodinia supercontinent and Neoproterozoic glaciations. Precambrian Res. 136, 107-123.

Xu, B.,Kou, X., Song, B., Wei, W., Wang, Y., 2008.SHRIMP dating of the upper Proterozoic volcanic rocks in the Tarim plate and constraints on the Neoproteorozoicglaciations.ActaPetrologicaSinica 24, 2857-2862 (in Chinese with English abstract).

Xu, B., Xiao, S., Zou, H., Chen, Y., Li, Z., Song, B., Liu, D., Zhou, C., Yuan, X., 2009. SHRIMP zircon U-Pb age constraints on NeoproterozoicQuruqtaghdiamictites in NW China. Precambrian Res. 168, 247-258.

Yin, C., Liu, D., Gao, L., Wang, Z., Xing, Y., Jian, P., Shi, Y., 2003. Lower boundary age of the Nanhua System and the Gucheng glacial stage: evidence from SHRIMPII dating. Chin. Sci. Bull. 48 (16), 1657-1662. 
Zhan, S., Chen, Y., Xu, B., Wang, B., Faure, M.,2007. Late Neoproterozoicpaleomagnetic results from the Sugetbrak Formation of the Aksu area, Tarim basin (NW China) and their implications to paleogeographic reconstructions and the snowball Earth hypothesis. Precambrian Res. 154, 143-158.

Zhang, B., Zhu, W., Jahn, B., Shu, L., Zhang, Z., Su, J., 2010. Subducted Precambrian oceanic crust: geochemical and $\mathrm{Sr}-\mathrm{Nd}$ isotopic evidence from metabasalts of the Aksublueschist, NW China. Journal of the Geological Society, London, 167, 1161-1170.

Zhang, C., Li, Z., Li, X., Ye, H., 2009. Neoproterozoic mafic dyke swarms at the northern margin of the Tarim Block, NW China: Age, geochemistry, petrogenesis and tectonic implications. Journal of Asian Earth Sciences 35, 167-179.

Zhang, C., Yang, D., Wang, H., Takahashi,Y., Ye, H., 2011. Neoproterozoic mafic-ultramafic layered intrusion in Quruqtagh of northeastern Tarim Block, NW China: Two phases of mafic igneous activity with different mantle sources. Gondwana Research 19, 177-190.

Zhang, L., Jiang, W., Wei, C., Dong, S., 1999. Discovery of deerite from the Aksu Precambrian blueschistterrane and its geological significance.Science in China (series D) 42, 233-239.

Zhang, S., Jiang, G., Zhang, J., Song, B., Kennedy, M.J., Christie-Blick, N., 2005. U-Pb sensitive high-resolution ion microprobe ages from the Doushantuo Formation in south China: constraints on late Neoproterozoic glaciations. Geology 33, 473-476.

Zhang, Z. C., Kang, J. L., Kusky, T., Santosh, M., Huang, H., Zhang, D. Y. and Zhu, J., 2012.Geochronology, geochemistry and petrogenesis of Neoproterozoic basalts fromSugetbrak, northwest Tarim block, China: Implications for the onset of Rodiniasupercontinent breakup. Precambrian Research 220-221, 158-176. 
Zhou, C., Tucker, R., Xiao, S., Peng, Z., Yuan, X., Chen, Z., 2004.Newconstraints on the ages of Neoproterozoic glaciations in South China.Geology 32, 437-440.

Zhu, W., Zheng, B., Shu, L., Ma, D., Wu, H., Li, Y., Huang, W., Yu, J., 2011.Neoproterozoic tectonic evolution of the Precambrian Aksublueschistterrane, northwestern Tarim, China: Insights from LA-ICP-MS zircon U-Pb ages and geochemical data. Precambrian Res. 185, 215-230.

Zou, H. B.,Zindler, A., 1996. Constraints on the degree of dynamic partial melting and source composition using concentration ratios in magmas.GeochimicaetCosmochimicaActa60, 711-717.

Zou, H. B., 1998.Trace element fractionation during modal and nonmodal dynamic melting and open-system melting: A mathematical treatment. GeochimicaetCosmochimicaActa 62, 1937-1945.

Zou, H. B., Zindler, A., Xu, X. S. and Qi, Q., 2000.Major, trace element, and Nd, Sr and $\mathrm{Pb}$ isotope studies of Cenozoic basalts in SE China: mantle sources, regional variations and tectonic significance. Chemical Geology 171, 33-47.

\section{Figure Captions}

Fig. 1. (A): Tectonic location of the Tarim Block in China; (B): Geological map of the Tarim Block, WestChina, showing the distribution of Neoproterozoic and the study area. Legend-PH: Phanerozoicrocks; NP: Neoproterozoic rocks; MP: Mesoproterozoic rocks; PP: Palaeoproterozoic rocks; AR:

Archaean rocks; NPG: early Neoproterozoic granitoids; F: faults; IF: inferred Faults; Tillite: Neoproterozoic tillite; Q: Quaternary desert and sedimentary deposits (modified after Lu, et al., 2008); (C): Geological map of the Aksu area (modified after Gao, et al., 1985; Turner, 2010).

Fig. 2. (A): Geological map of the Sugetbrak area and sample positions (modified after BGMRED ofXinjiang, 1993); (B): the Neoproterozoic stratigraphic column of the Sugetbrak area; (C): Photographof the Neoproterozoic succession in the Sugetbrak area.Notice the positions of SB sample 05822 . 
Fig.3. Photographs of the SB and sedimentary rocks of the Sugetbrak Formation. (A): largeherringbone and conformity relationships between the SB and underlying sandstone; (B): columnar joints of the SB; (C): Continuous distribution of the SB on the south limb of a syncline; (D): pillow lava in the SB; (E): conformity relationship between the SB and overlying red sandstones;(F): ripple bedding in red sandstone of the Lower member of the Sugetbrak Fm.

Fig. 4. A: Cathodoluminescence images of zircons from the SB.Notice the zircons can be dividedinto 3 groups according to their sizes; B: Concordia plot of zircons from sample 05822 of the $\mathrm{SB}$;

C: Concordia plot of zircons from sample 05823 of the SB.

Fig.5. A: $\mathrm{Zr} / \mathrm{TiO}_{2}-\mathrm{Nb} / \mathrm{Y}$ diagram (Winchester and Floyd, 1977); B: Nb/Y $\mathrm{Zr} /\left(\mathrm{P}_{2} \mathrm{O}_{5} * 10000\right)$ diagram (Floyd and Winchester, 1975)

Fig. 6. A: REE diagram of the SB; B: Trace element spider diagram of the SB.

Fig. 7. A: Ti-Zr-Y diagram (Pearce and Cann, 1973); B: Nb-Zr-Y diagram (Meschede, 1986)

Fig. 8. Correlation of the Neoproterozoic between the southwest Aksu, Wushi and Sugetbrak sections in the northwest Tarim Block.

Fig. 9. Correlation of Neoproterozoic glaciations between the northeast Tarim, northwest Tarim and Yangtze Blocks. Data from: Yin et al., 2003; Hoffmann et al., 2004; Zhou et al., 2004; Chu et al., 2005; Condon et al., 2005; Zhang et al., 2005; Kendall et al., 2006; Xu et al., 2009. 


\begin{tabular}{|c|c|c|c|c|c|c|c|}
\hline Spot & $\mathrm{U}$ (ppm) & Th (ppm) & ${ }^{232} \operatorname{Th} /{ }^{238} \mathrm{U}$ & ${ }^{206} \mathrm{~Pb}_{\mathrm{c}}$ & ${ }^{206} \mathrm{~Pb}$ * & ${ }^{206} \mathrm{~Pb} /{ }^{238} \mathrm{U}$ Age & ${ }^{207} \mathrm{~Pb} / /^{201}$ \\
\hline $22-1-1.1$ & 246 & 147 & 0.62 & 0.13 & 28.9 & $825.4 \pm 8.9$ & 849 \\
\hline $22-1-2 \cdot 1$ & 287 & 179 & 0.64 & 0.30 & 33.0 & $808.0 \pm 8.4$ & 808 \\
\hline $22-1-3.1$ & 355 & 412 & 1.20 & 0.16 & 37.3 & $743.4 \pm 7.6$ & 737 \\
\hline $22-1-4.1$ & 451 & 209 & 0.48 & 0.14 & 49.6 & $774.6 \pm 7.9$ & 771 \\
\hline $22-1-5.1$ & 180 & 205 & 1.17 & 0.26 & 18.4 & $722.2 \pm 8.1$ & 671 \\
\hline $22-1-6.1$ & 159 & 146 & 0.95 & 0.27 & 17.5 & $776.1 \pm 8.8$ & 779 \\
\hline $22-1-7.1$ & 240 & 164 & 0.71 & 0.63 & 20.9 & $617.3 \pm 6.8$ & 641 \\
\hline $22-1-8.1$ & 58 & 63 & 1.13 & 0.85 & 6.10 & $744 \pm 11$ & 797 \\
\hline $22-1-9.1$ & 960 & 536 & 0.58 & 2.44 & 104 & $750.8 \pm 7.3$ & 774 \\
\hline $2-1-10.1$ & 171 & 132 & 0.80 & 0.25 & 19.5 & $804.2 \pm 8.8$ & 825 \\
\hline $2-1-11 \cdot 1$ & 517 & 425 & 0.85 & 0.75 & 64.0 & $861.9 \pm 8.7$ & 808 \\
\hline $822-12.1$ & 63 & 67 & 1.11 & 0.36 & 6.96 & \pm 10 & 639 \\
\hline $822-13.1$ & 155 & 104 & 0.69 & 16.79 & 18.6 & $707 \pm 16$ & 590 \\
\hline $2-1 \mathrm{~A}-1.1$ & 72 & 83 & 1.19 & 0.30 & 7.57 & $743.3 \pm 7.5$ & 833 \\
\hline $2-1 A-2.1$ & 284 & 83 & 0.30 & 0.06 & 32.5 & $805.9 \pm 4.2$ & 820 \\
\hline $2-1 A-3.1$ & 71 & 82 & 1.19 & 0.67 & 7.78 & $773.0 \pm 8.0$ & 703 \\
\hline $2-1 A-4.1$ & 87 & 89 & 1.06 & 1.57 & 9.48 & $758.9 \pm 7.6$ & 712 \\
\hline $2-1 A-5.1$ & 442 & 111 & 0.26 & 0.13 & 38.0 & $614.9 \pm 2.6$ & 671 \\
\hline $2-1 A-6.1$ & 361 & 416 & 1.19 & 0.24 & 40.6 & $790.4 \pm 3.7$ & 816 \\
\hline $2-1 A-7.1$ & 832 & 305 & 0.38 & 0.51 & 103 & $863.6 \pm 3.2$ & 841 \\
\hline $3-11-1.1$ & 233 & 151 & 0.67 & 0.48 & 27.3 & $821.2 \pm 9.5$ & 760 \\
\hline $3-11-2.1$ & 1102 & 816 & 0.77 & 0.69 & 95.7 & $616.6 \pm 6.6$ & 694 \\
\hline $3-11-3.1$ & 568 & 741 & 1.35 & 0.32 & 54.1 & $676.2 \pm 7.5$ & 657 \\
\hline $3-11-4.1$ & 415 & 200 & 0.50 & 0.12 & 110 & $1,735 \quad \pm 17$ & $1,755.6$ \\
\hline $3-11-5.1$ & 623 & 949 & 1.58 & 0.22 & 53.4 & $612.3 \pm 6.5$ & 663 \\
\hline $3-11-6.1$ & 762 & 558 & 0.76 & 0.37 & 73.7 & $685.6 \pm 7.3$ & 689 \\
\hline $3-11-7.1$ & 140 & 216 & 1.59 & 0.92 & 16.9 & $839 \pm 11$ & 698 \\
\hline $3-11-8.1$ & 588 & 261 & 0.46 & 0.20 & 57.3 & $691.4 \pm 7.3$ & 778 \\
\hline $3-11-9.1$ & 461 & 184 & 0.41 & 0.15 & 52.8 & $806.8 \pm 8.8$ & 801 \\
\hline
\end{tabular}

Errors are 1-sigma; $\mathrm{Pb}_{\mathrm{c}}$ and $\mathrm{Pb}^{*}$ indicate the common and radiogenic portions, respective Error in Standard calibration was $0.20 \%$ ( not included in above errors but required whe (1) Common $\mathrm{Pb}$ corrected using measured ${ }^{204} \mathrm{~Pb}$. (2) Common Pb corrected by assuming $206 \mathrm{~Pb}$ (3) Common $\mathrm{Pb}$ corrected by assuming ${ }^{206} \mathrm{~Pb} /{ }^{238} \mathrm{U}-{ }^{208} \mathrm{~Pb} /{ }^{232} \mathrm{Th}$ age-concordance. 
Table 2 Major and trace element abundances for the Sugetbrak basalts in Sugetbrak area, west Tarim BI

\begin{tabular}{|c|c|c|c|c|c|c|c|c|}
\hline Sample & $831 S 41$ & $831 \mathrm{~S} 51$ & $830 S 2$ & 83156 & 83158 & 83160 & 83161 & 83163 \\
\hline $\mathrm{SiO}_{2}$ & 44.35 & 43.45 & 45.40 & 44.38 & 45.47 & 45.44 & 46.81 & 44.37 \\
\hline $\mathrm{TiO}_{2}$ & 4.002 & 3.494 & 3.763 & 3.124 & 2.865 & 2.215 & 2.216 & 2.489 \\
\hline $\mathrm{Al}_{2} \mathrm{O}_{3}$ & 13.91 & 14.91 & 13.92 & 14.9 & 15.32 & 16.95 & 16.73 & 17.73 \\
\hline $\mathrm{MgO}$ & 4.52 & 5.11 & 5.3 & 5.88 & 5.33 & 5.29 & 5.19 & 6.44 \\
\hline $\mathrm{Fe}_{2} \mathrm{O}_{3}$ & 16.47 & 13.76 & 16.46 & 16.34 & 15.38 & 13.22 & 13.5 & 12.52 \\
\hline $\mathrm{MnO}$ & 0.241 & 0.643 & 0.251 & 0.236 & 0.2 & 0.131 & 0.125 & 0.16 \\
\hline $\mathrm{CaO}$ & 8.00 & 8.21 & 8.00 & 5.45 & 7.30 & 7.18 & 5.98 & 4.84 \\
\hline $\mathrm{K}_{2} \mathrm{O}$ & 0.28 & 0.62 & 0.66 & 1.23 & 1.18 & 1.41 & 1.67 & 0.59 \\
\hline $\mathrm{Na}_{2} \mathrm{O}$ & 4.01 & 3.16 & 2.93 & 3.3 & 2.48 & 3.36 & 3.59 & 3.75 \\
\hline $\mathrm{P}_{2} \mathrm{O}_{5}$ & 0.66 & 0.598 & 0.635 & 0.481 & 0.457 & 0.452 & 0.462 & 0.468 \\
\hline LOI & 3.57 & 6.06 & 2.72 & 4.8 & 4.07 & 4.45 & 3.83 & 6.9 \\
\hline Total & 100.01 & 100.02 & 100.04 & 100.13 & 100.05 & 100.09 & 100.11 & 100.26 \\
\hline $\mathrm{Ti}$ & 24519 & 21911 & 23322 & 19024 & 17451 & 13702 & 13690 & 15193 \\
\hline $\mathrm{Rb}$ & 6.56 & 12.68 & 10.31 & 17.23 & 17.42 & 22.93 & 29.61 & 8.86 \\
\hline $\mathrm{Sr}$ & 718 & 474 & 474 & 342 & 383 & 464 & 442 & 335 \\
\hline Y & 37.2 & 33.2 & 35.2 & 33.9 & 33.3 & 26.3 & 26.9 & 27.6 \\
\hline $\mathrm{Zr}$ & 200 & 183 & 192 & 190 & 188 & 150 & 152 & 158 \\
\hline $\mathrm{Nb}$ & 24.63 & 22.58 & 23.23 & 21.49 & 21.07 & 16.24 & 16.27 & 17.64 \\
\hline Cs & 0.16 & 0.41 & 0.28 & 0.15 & 0.07 & 0.11 & 0.12 & 0.30 \\
\hline $\mathrm{Ba}$ & 121 & 292 & 444 & 831 & 889 & 696 & 705 & 327 \\
\hline $\mathrm{Hf}$ & 4.79 & 4.38 & 4.80 & 4.55 & 4.47 & 3.71 & 3.68 & 3.87 \\
\hline $\mathrm{Ta}$ & 1.60 & 1.42 & 1.54 & 1.38 & 1.35 & 1.03 & 1.02 & 1.11 \\
\hline $\mathrm{Pb}$ & 4.02 & 14.93 & 4.01 & 1.70 & 2.67 & 3.46 & 3.58 & 6.64 \\
\hline Th & 2.99 & 2.72 & 2.81 & 2.16 & 2.11 & 1.75 & 1.77 & 1.83 \\
\hline$U$ & 0.68 & 0.66 & 0.62 & 1.27 & 0.54 & 0.41 & 0.40 & 0.45 \\
\hline
\end{tabular}

Table2 (continued)

\begin{tabular}{lrrrrrrrr}
\hline Sample & $831 S 41$ & $831 S 51$ & $830 S 2$ & 83156 & 83158 & 83160 & 83161 & 83163 \\
\hline $\mathrm{La}$ & 37.42 & 33.39 & 34.29 & 28.31 & 26.41 & 26.43 & 26.29 & 26.38 \\
$\mathrm{Ce}$ & 74.41 & 67.07 & 68.73 & 55.70 & 52.86 & 51.41 & 51.42 & 51.79 \\
$\mathrm{Pr}$ & 9.22 & 8.53 & 8.81 & 7.31 & 7.17 & 6.65 & 6.60 & 6.84 \\
$\mathrm{Nd}$ & 39.80 & 36.03 & 36.61 & 32.03 & 30.63 & 27.98 & 28.56 & 29.78 \\
$\mathrm{Sm}$ & 8.08 & 7.36 & 7.65 & 6.66 & 6.59 & 5.80 & 5.80 & 6.17 \\
$\mathrm{Eu}$ & 2.66 & 2.46 & 2.52 & 2.32 & 2.30 & 2.21 & 2.15 & 2.40 \\
$\mathrm{Gd}$ & 8.62 & 7.95 & 8.27 & 7.32 & 7.09 & 6.04 & 6.28 & 6.41 \\
$\mathrm{~Tb}$ & 1.10 & 1.00 & 1.06 & 0.98 & 0.93 & 0.80 & 0.78 & 0.81 \\
$\mathrm{Dy}$ & 7.01 & 6.40 & 6.65 & 6.37 & 6.02 & 4.99 & 5.15 & 5.17 \\
$\mathrm{Ho}$ & 1.44 & 1.30 & 1.36 & 1.30 & 1.24 & 1.04 & 1.03 & 1.06 \\
$\mathrm{Er}$ & 3.74 & 3.45 & 3.63 & 3.31 & 3.37 & 2.77 & 2.76 & 2.86 \\
$\mathrm{Tm}$ & 0.51 & 0.46 & 0.48 & 0.46 & 0.45 & 0.36 & 0.36 & 0.38 \\
$\mathrm{Yb}$ & 2.81 & 2.68 & 2.76 & 2.69 & 2.68 & 2.11 & 2.19 & 2.19 \\
$\mathrm{Lu}$ & 0.44 & 0.42 & 0.43 & 0.45 & 0.42 & 0.33 & 0.34 & 0.34 \\
\hline
\end{tabular}




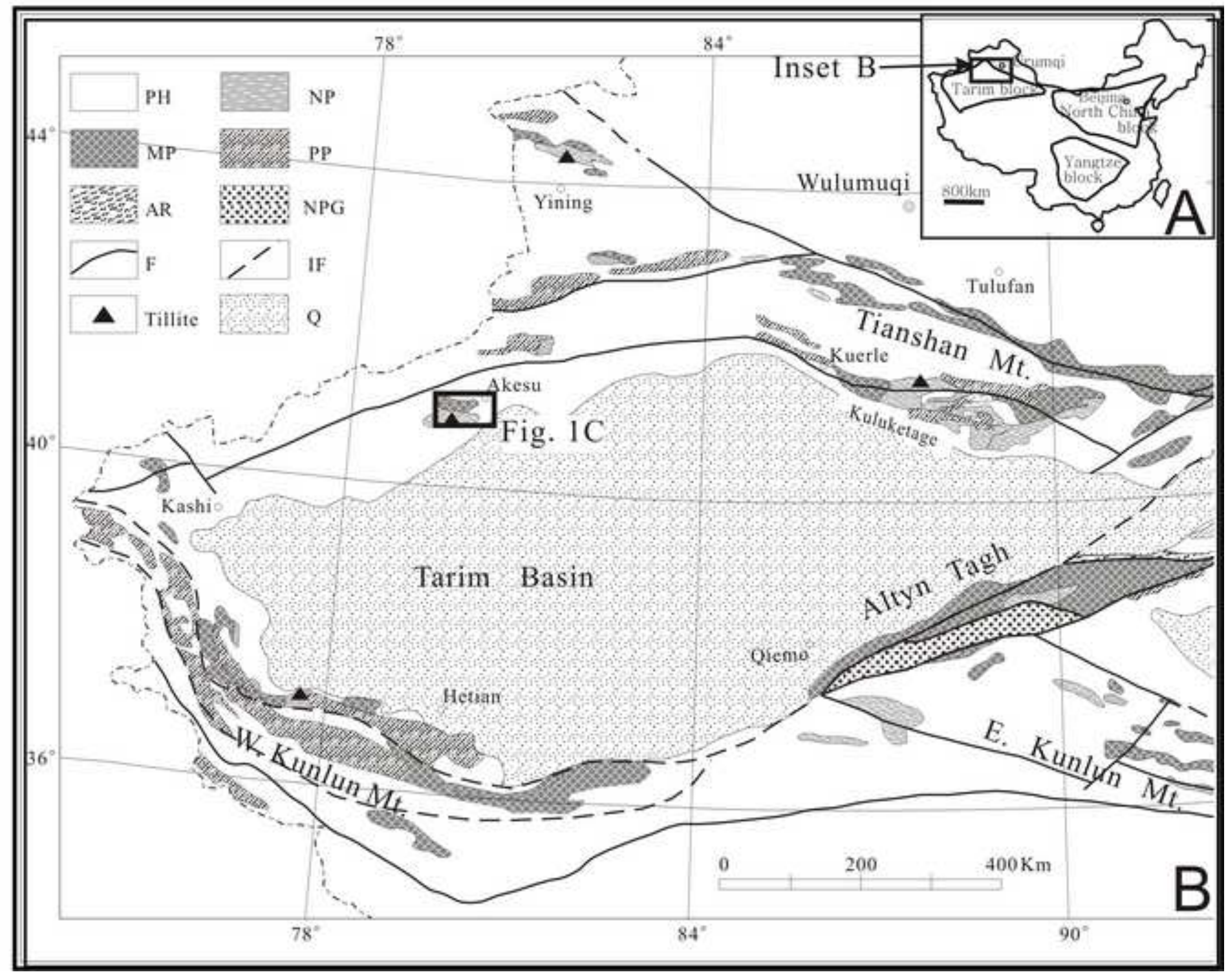




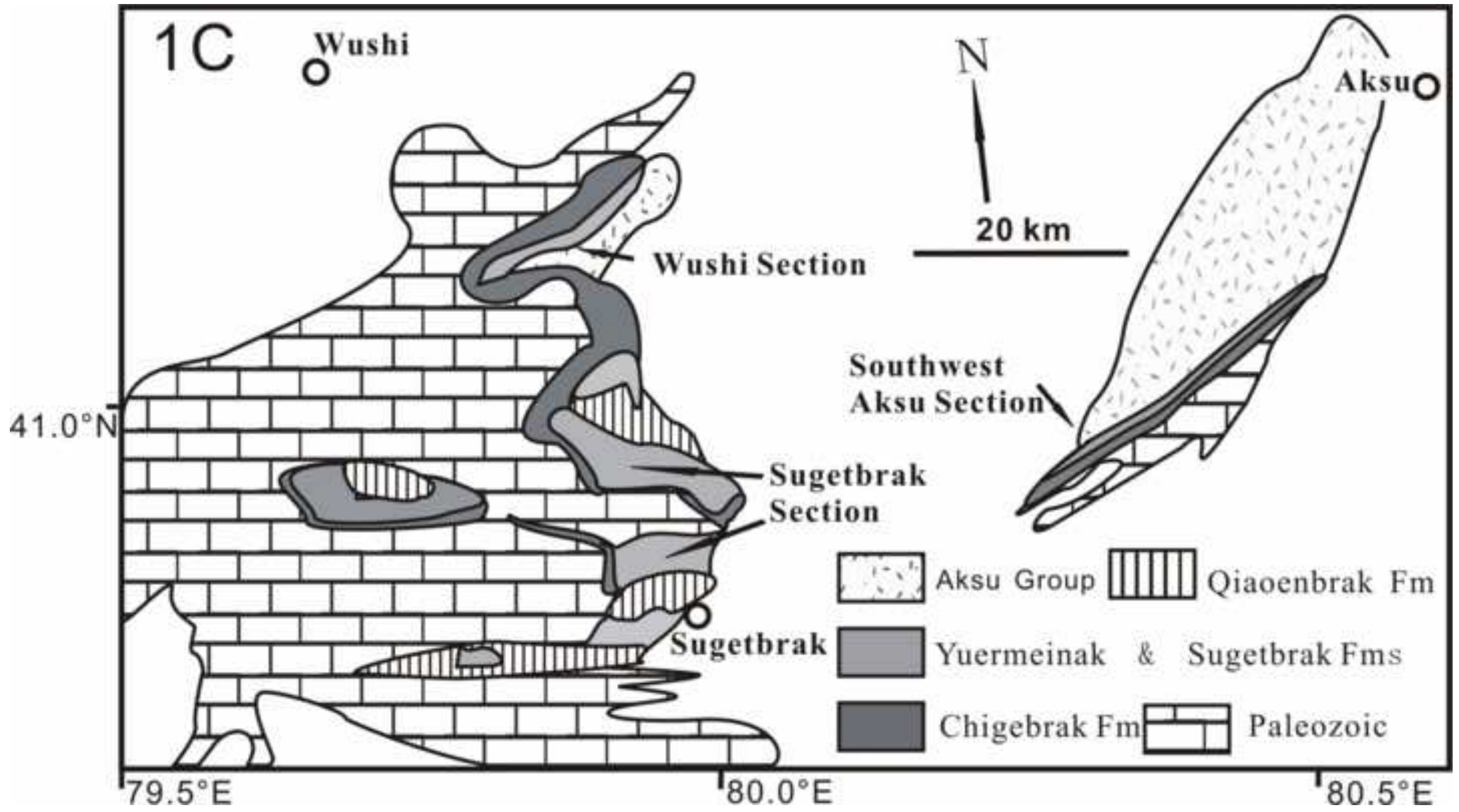




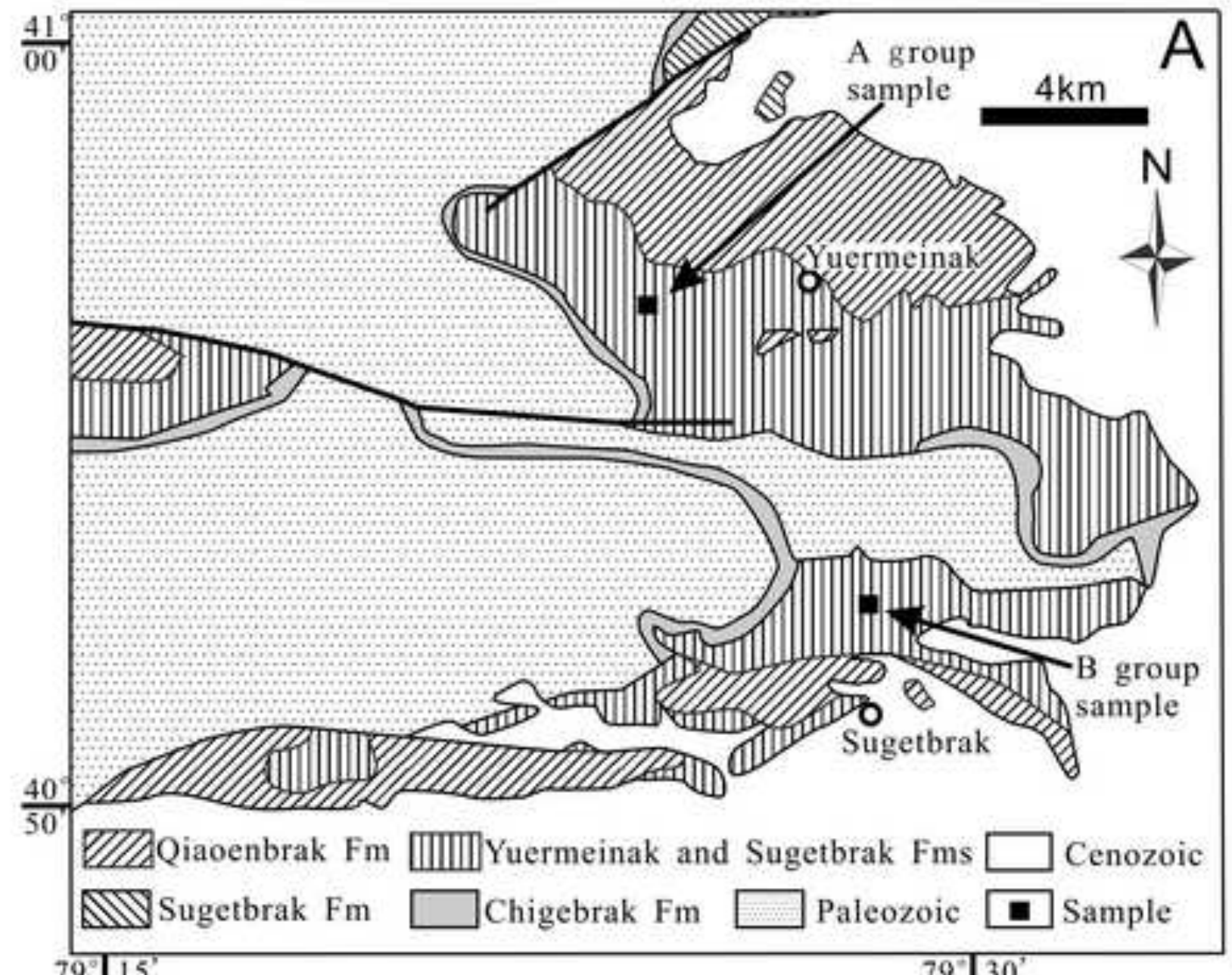

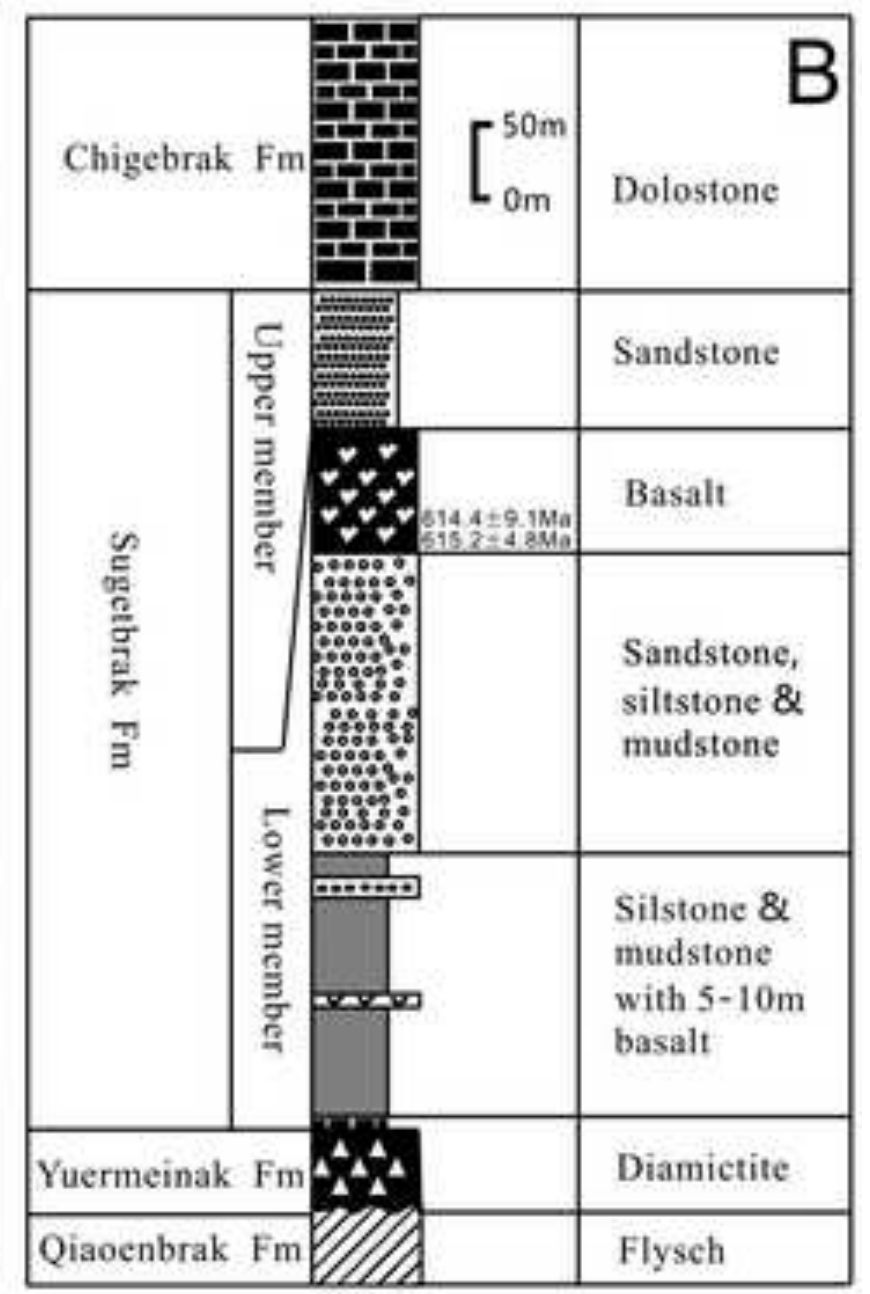




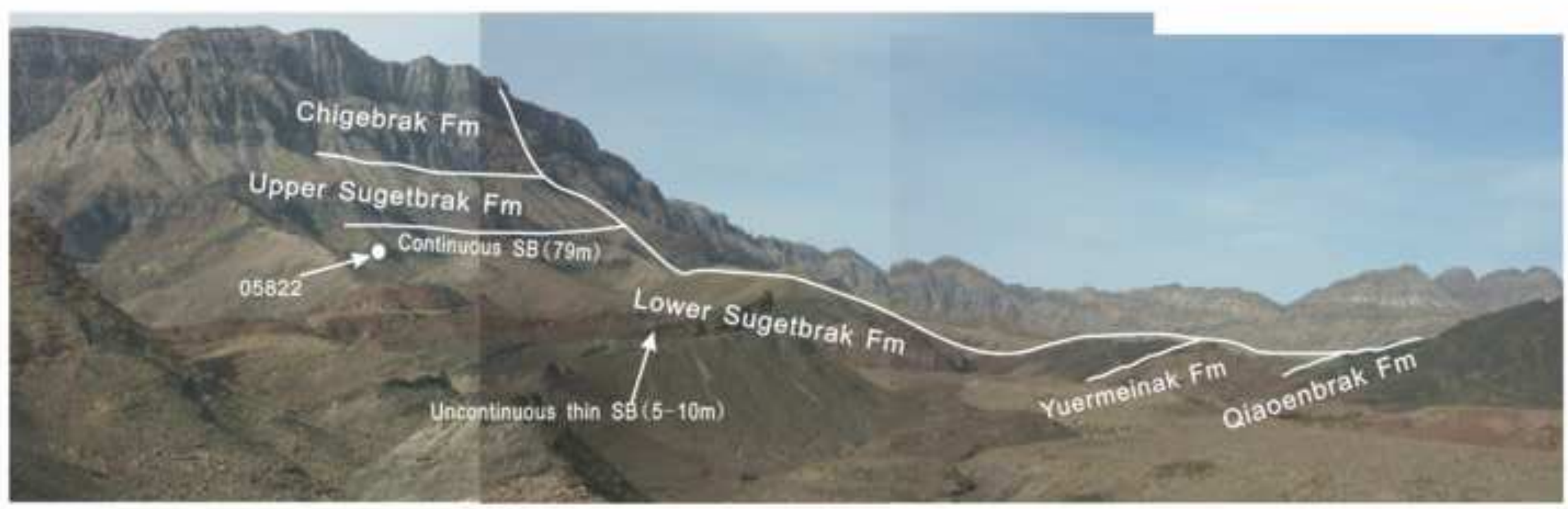



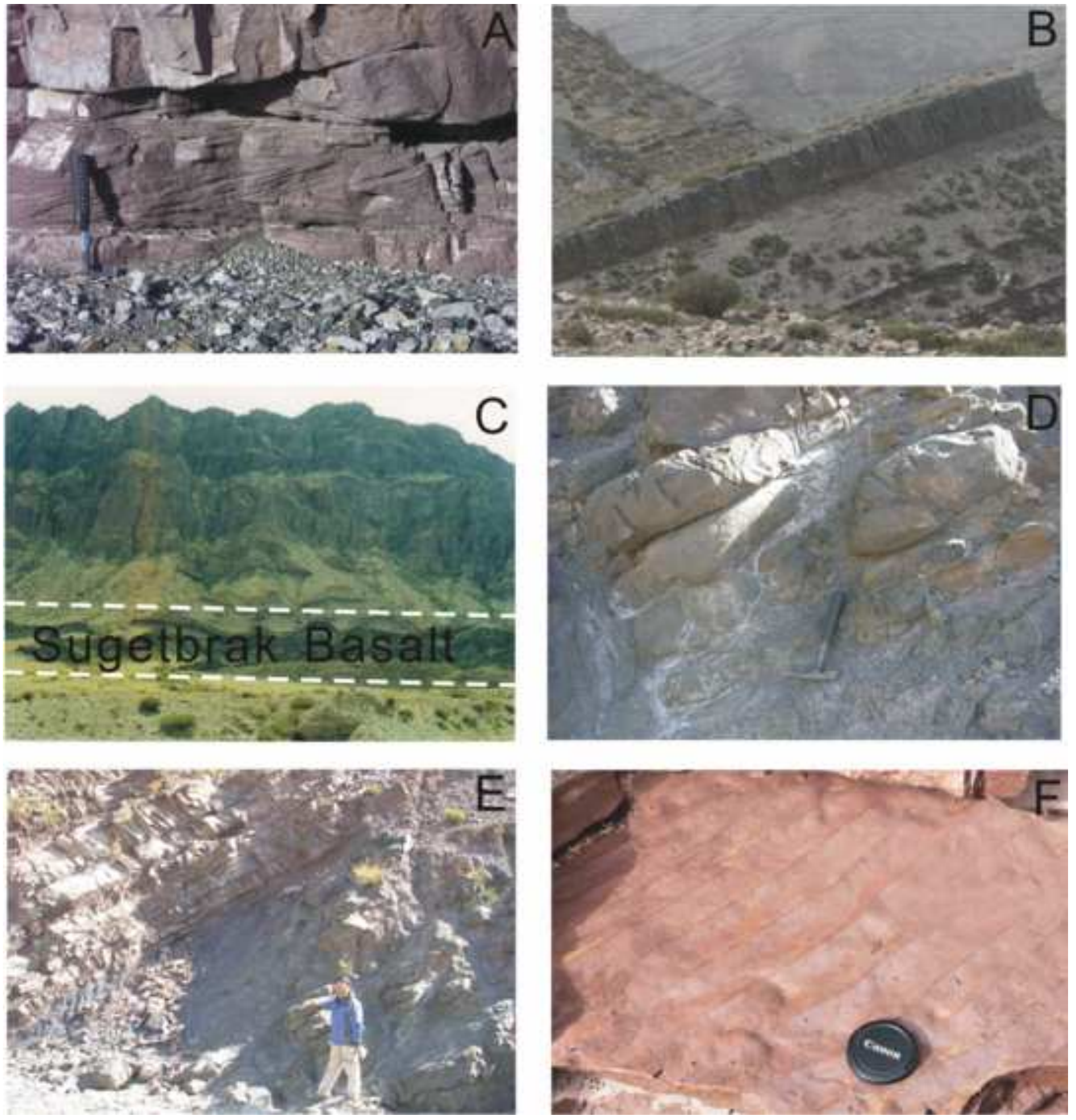


\section{$825 \pm 9 M a$}

\section{2}

$100 \mu \mathrm{m}$

\section{$722 \pm 8 \mathrm{Ma}$}

$617 \pm 7 \mathrm{Ma}$

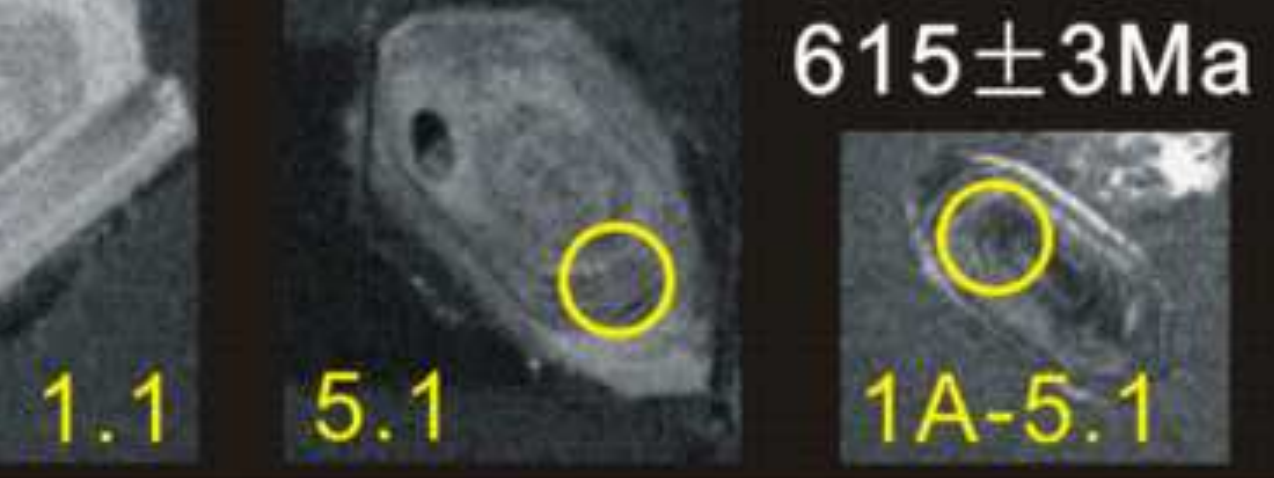

05823-11

$1756 \pm 9 M a$

$821 \pm 10 \mathrm{Ma}$

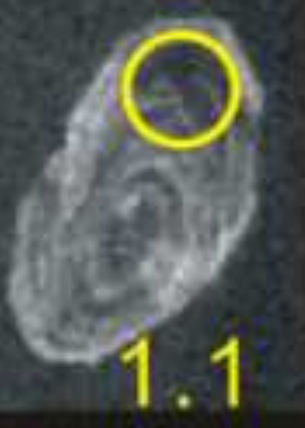

$617 \pm 7 \mathrm{Ma}$

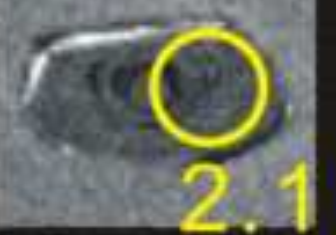

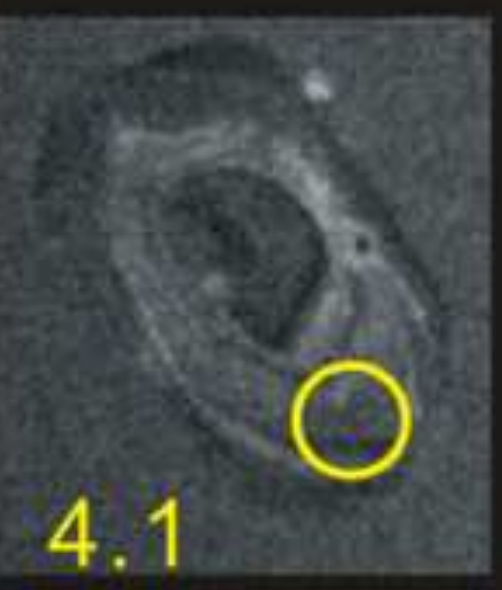

$100 \mu \mathrm{m}$

$612 \pm 7 \mathrm{Ma}$

$691 \pm 7 \mathrm{Ma}$

○

5.1

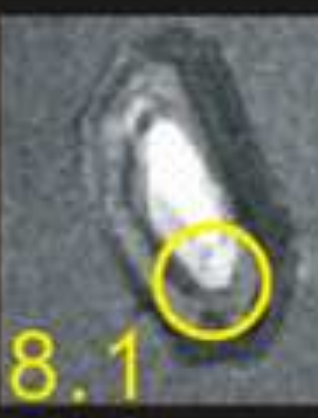




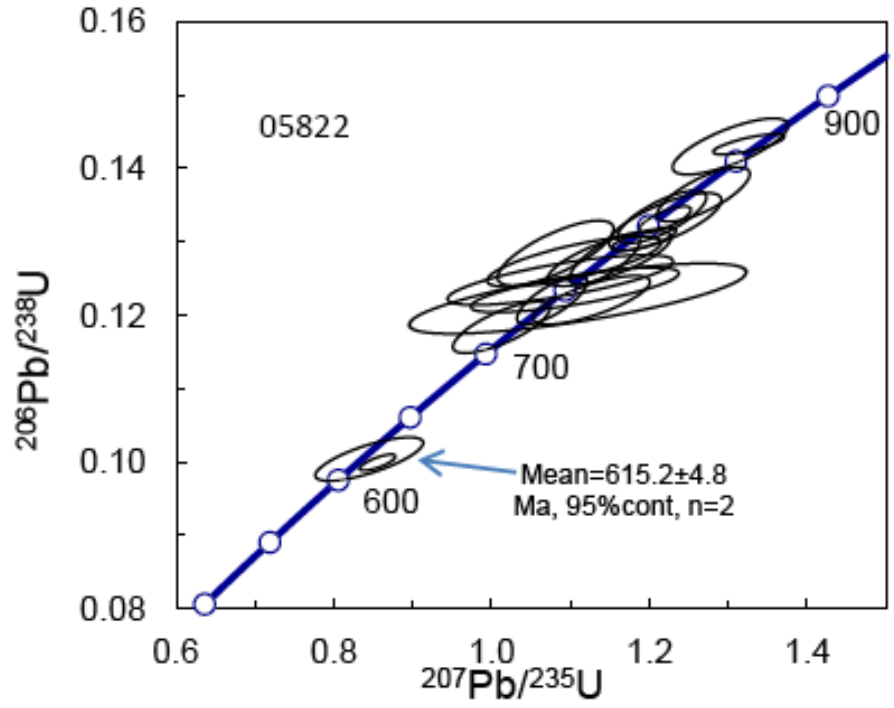

Fig.4B

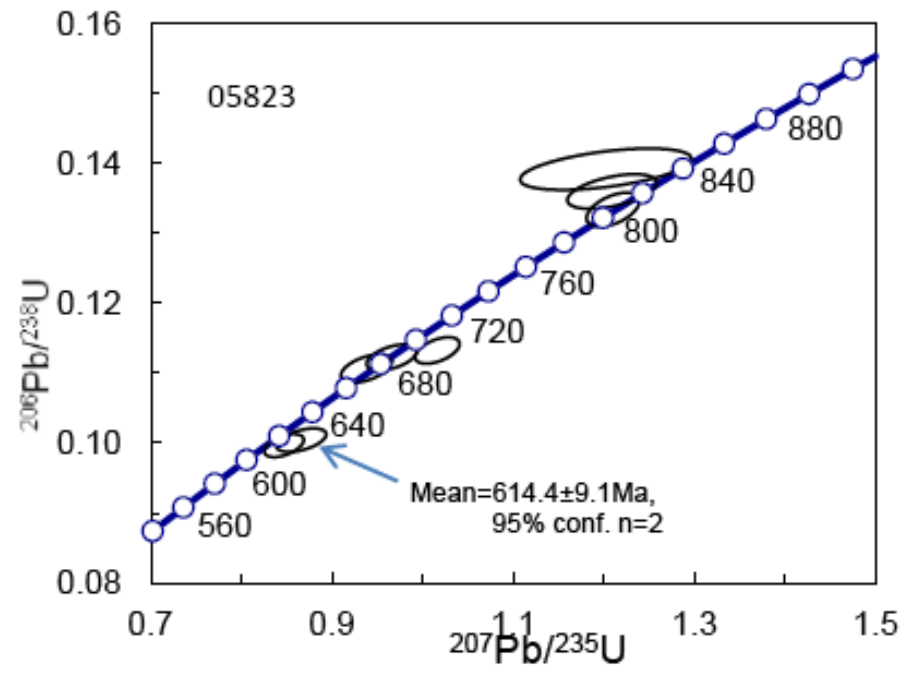

Fig.4C 


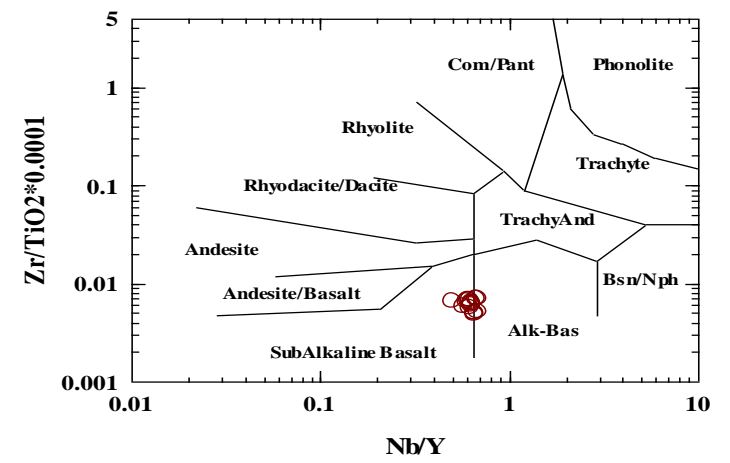

Fig.5A

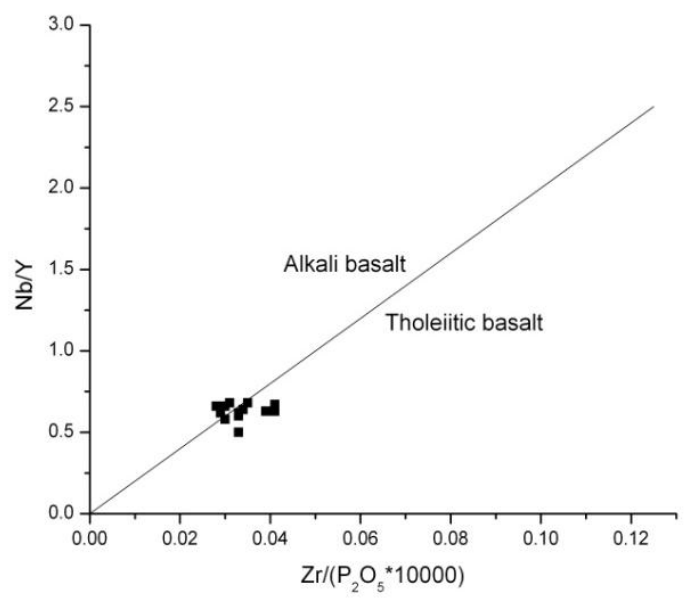

Fig.5B 


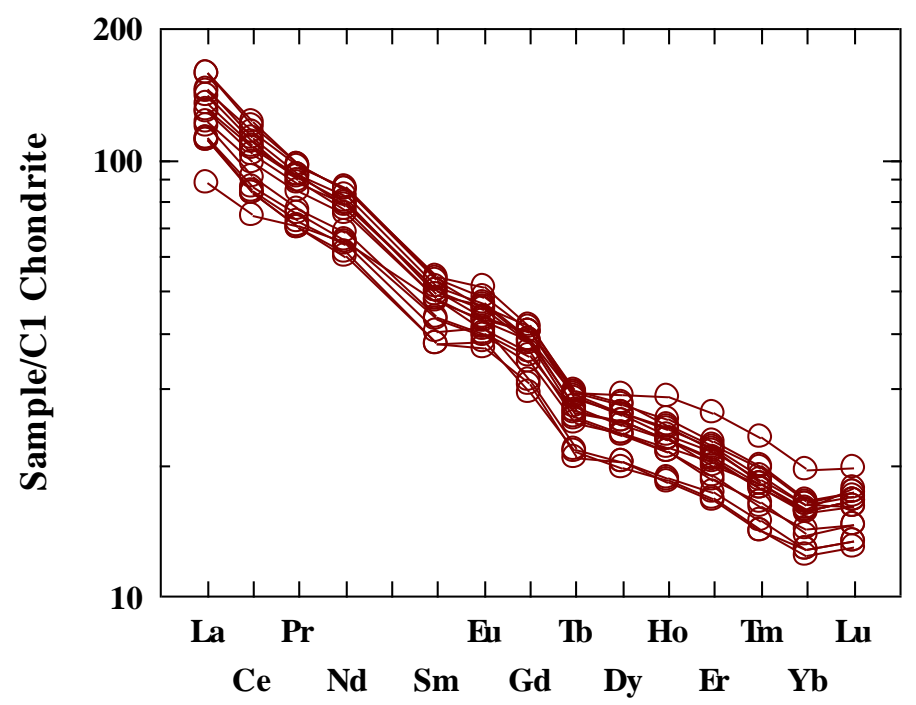

Fig.6A

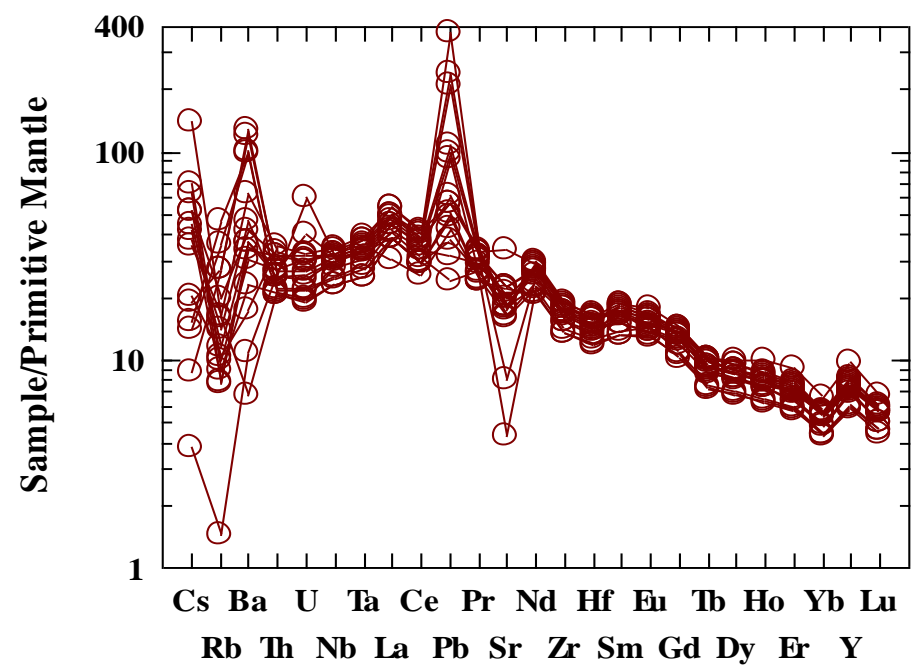

Fig.6B 


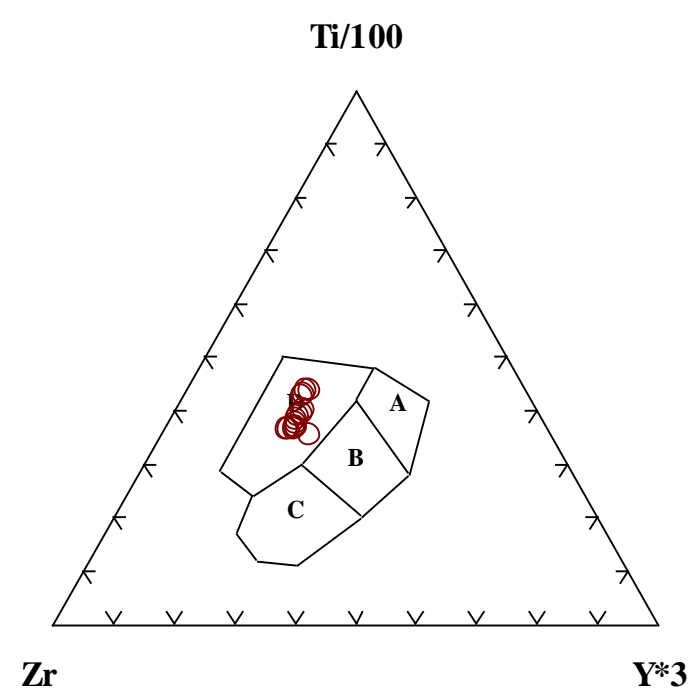

Fig.7A

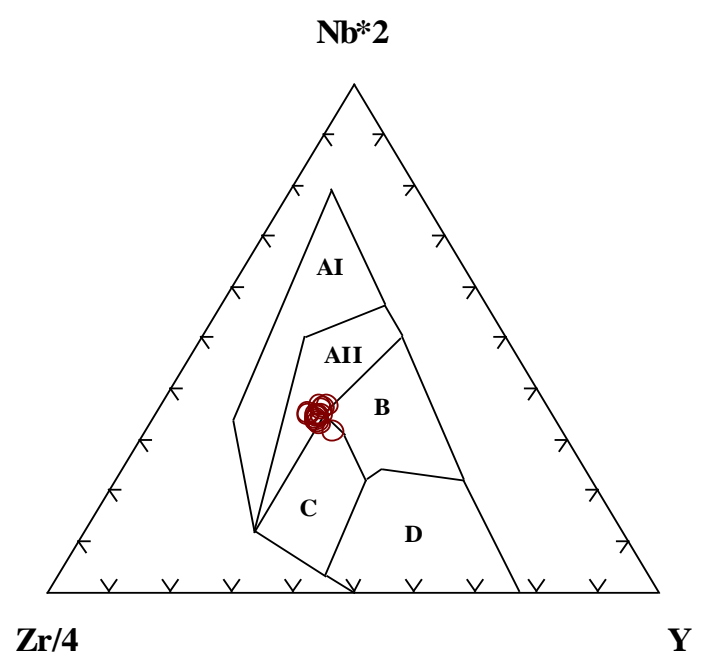

Fig.7B 
Sugetbrak section
Southwest

Aksu section
Wushi

\section{section}

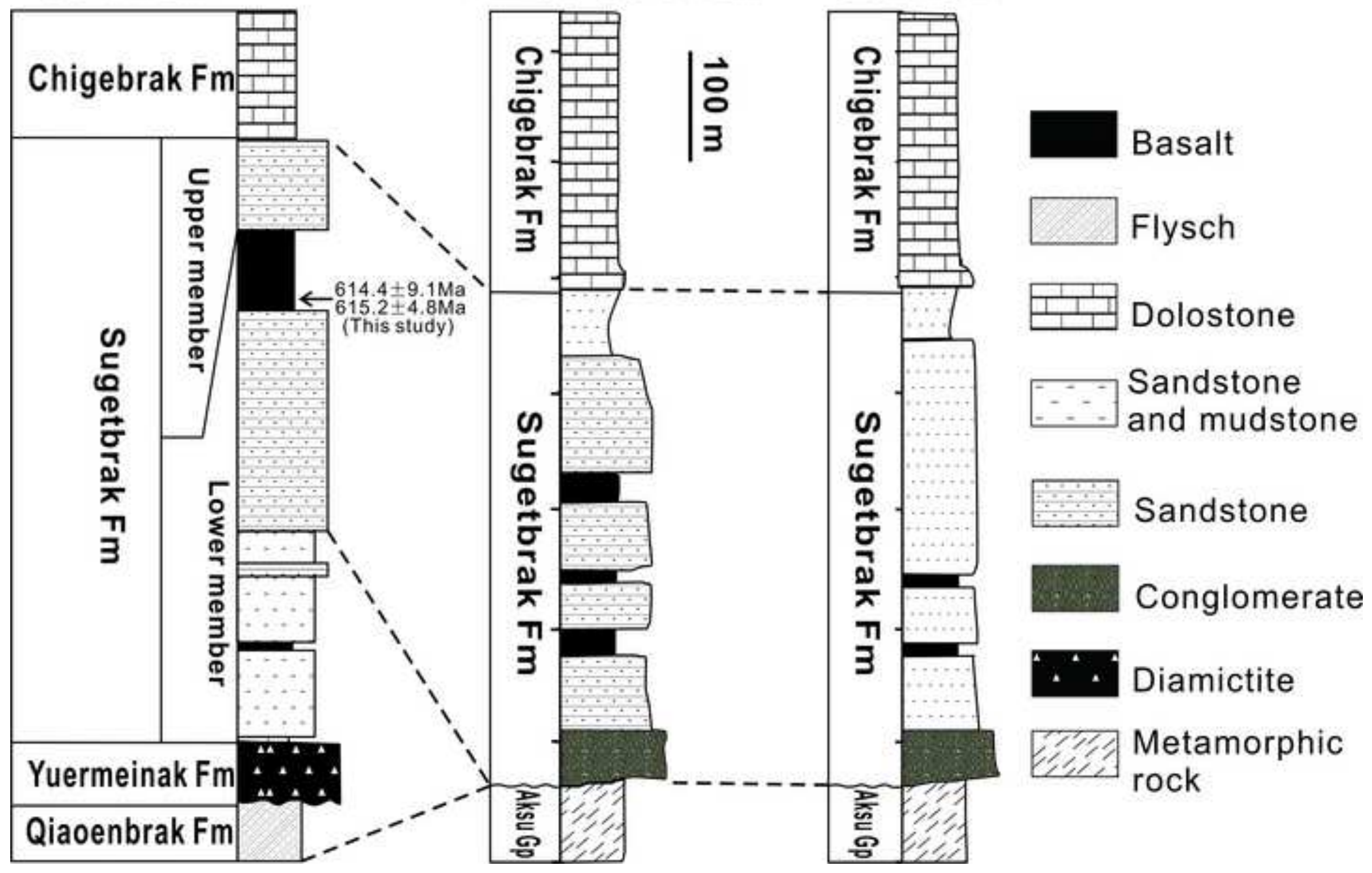


Tarim Block Tarim Block Yangtze Interpretative (northeast) (northwest) Block Column

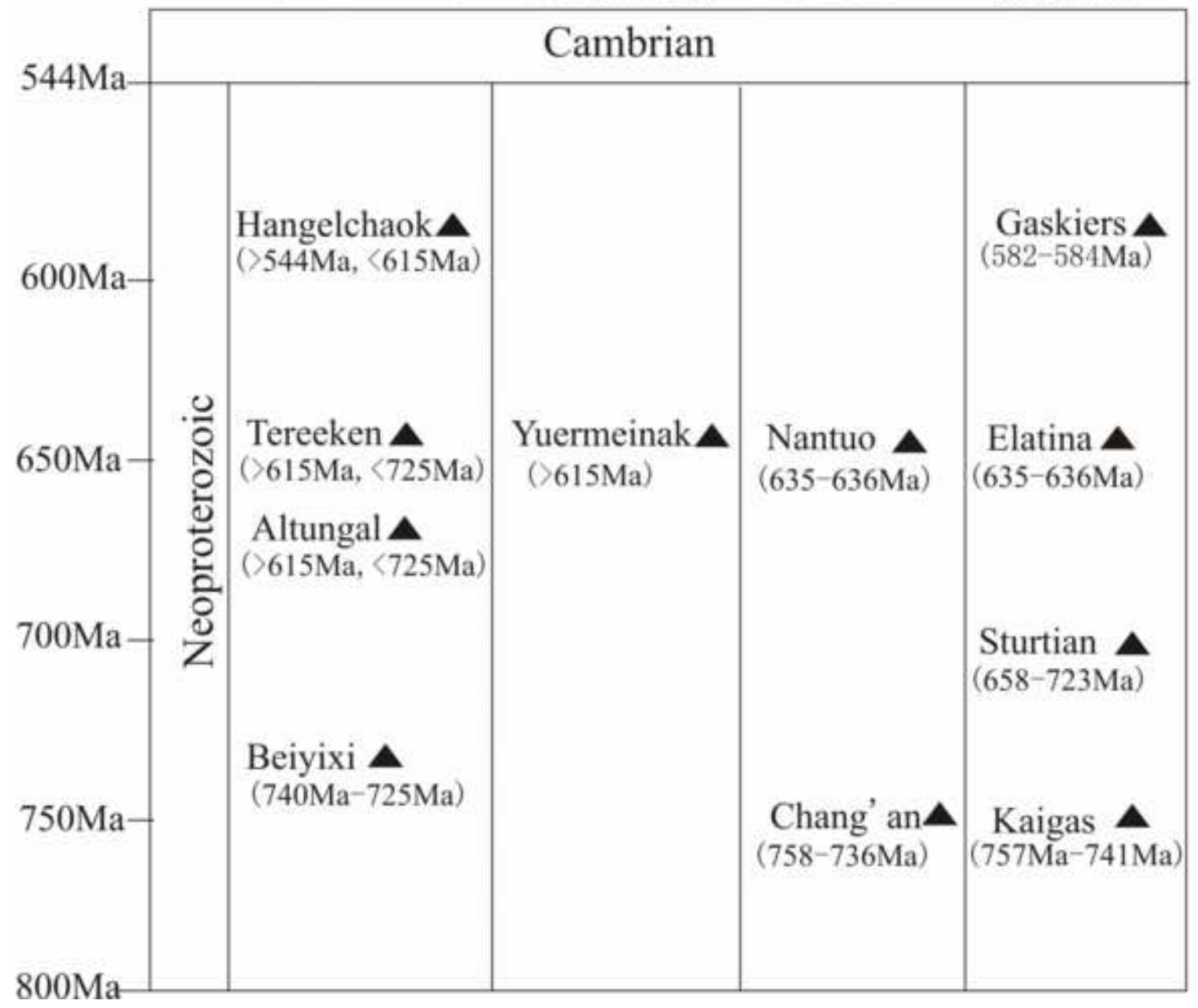

